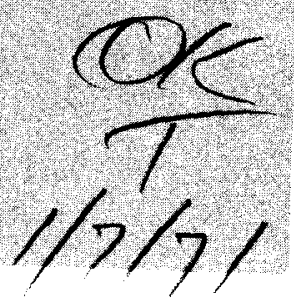

\title{
DEVELOPMENT OF A FLUIDIZED-BED BURNER FOR PROCESSING ROVER FUEL
}

L. C. Borduin D. C. Kilian A. P. Roeh

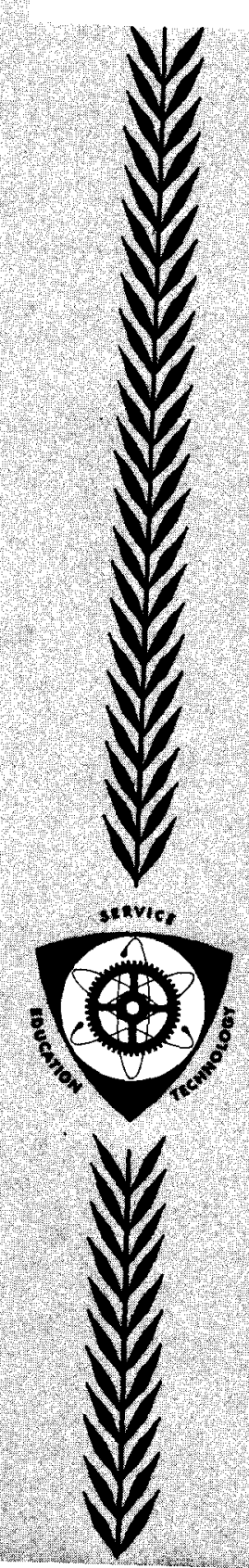

THIS DOCUNENT CONFIRMED AS UNCLASSIFIED DIVISION OF CLASSIFICATION

BY DAfe 7 HKahno fanta

IDAHO NUCLEAR CORPORATION NATIONAL REACTOR TESTING STATION IDAHO FALLS. IDAHO 83401

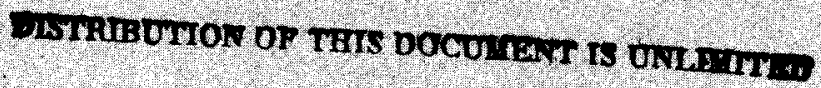

PREPARED FOR

U. S. ATOMIC ENERGY COMMISSION IDAHO OPERATIONS OFFICE UNDER CONTRACT NO. AT(10-1)-1230 
Printed in the United States of America

Available from

Clearinghouse for Federal Scientific and Technical Information

National Bureau of Standards, U. S. Department of Commerce

Springfield, Virginia 22151

Price: Printed Copy $\$ 3.00$; Microfiche $\$ 0.65$

\section{LEGAL NOTICE}

This report was prepared as an account of Government sponsored work. Neither the United States, nor the Commission, nor any person acting on behalf of the Commission:

A. Makes any warranty or representation, express or implied, with respect to the accuracy, completeness, or usefulness of the information contained in this report, or that the use of any information, apparatus, method, or process disclosed in this report may not infringe privately owned rights; or

B. Assumes any liabilities with respect to the use of, or for damages resulting from the use of any information, apparatus, method, or process disclosed in this report.

As used in the above, "person acting on behalf of the Commission" includes any employee or contractor of the Commission, or employee of such contractor, to the extent that such employee or contractor of the Commission, or employee of such contractor prepares, disseminates, or provides access to, any information pursuant to his employment or contract with the Commission, or his employment with such contractor. 


\section{DISCLAIMER}

This report was prepared as an account of work sponsored by an agency of the United States Government. Neither the United States Government nor any agency Thereof, nor any of their employees, makes any warranty, express or implied, or assumes any legal liability or responsibility for the accuracy, completeness, or usefulness of any information, apparatus, product, or process disclosed, or represents that its use would not infringe privately owned rights. Reference herein to any specific commercial product, process, or service by trade name, trademark, manufacturer, or otherwise does not necessarily constitute or imply its endorsement, recommendation, or favoring by the United States Government or any agency thereof. The views and opinions of authors expressed herein do not necessarily state or reflect those of the United States Government or any agency thereof. 


\section{DISCLAIMER}

Portions of this document may be illegible in electronic image products. Images are produced from the best available original document. 
This report was prepared as an account of work sponsored by the United States Government. Neither the United States nor the United States Atomic Energy Commission, nor any of their employees, nor any of their contractors, subcontractors, or their employees, makes any warranty, express or implied, or assumes any legal liability or responsibility for the accuracy, completeness or usefulness of any information, apparatus, product or process disclosed, or represents that its use would not infringe privately owned rights.

\title{
DEVELOPMENT OF A FLUIDIZED-BED BURNER
}

FOR PROCESSING ROVER FUEL

\section{by}
L. C. Borduin
D. C. Kilian
A. P. Roeh

\section{IDAHO NUCLEAR CORPORATION}

\author{
A Jointly Owned Subsidiary of \\ AEROJET GENERAL CORPORATION \\ ALLIED CHEMICAL CORPORATION \\ PHILLIPS PETROLEUM COMPANY
}

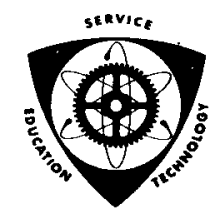

Date Published - November 1970 


\section{ACKNOWLEDGMENTS}

Appreciation is expressed to the following technicians for conducting the many pilot-plant runs required in the development program: A. Anderson, S. Hinckley, W. Lewis, D. Otteson, R. Ring, and H. Runz. 


\section{ABSTRACT}

Development of a fluidized-bed combustion process for recovering uranium from spent graphite-matrix nuclear rocket (Rover) fuels is described. The graphite matrix is removed by combustion in a bed of inert alumina particles fluidized by oxygen; the uranium and other metals in the fuel are converted to their oxides. Uranium oxide, $\mathrm{U}_{3} \mathrm{O}_{8}$, and other metallic oxides are removed from the burner by elutriation and enter the dissolution phase of the headend process. 


\section{SUMMARY}

Pilot-plant development of a fluidized-bed combustion process for the recovery of uranium from spent Rover fuel elements is approaching completion at the Idaho Chemical Processing Plant (ICPP). The burner operation includes the following steps: (1) charging whole Rover elements to the burner, (2) removing the graphite matrix by combustion in a bed of inert alumina particles fluidized by oxygen, and (3) separating the resulting uranium oxide, primarily $\mathrm{U}_{3} \mathrm{O}_{8}$, from the fluidized bed by elutriation. Dissolution of the burner product to obtain a solution suitable for solvent extraction completes the headend process.

The combustion vessel design which evolved from this development program is the two-stage concentric fluidized-bed burner. The lower first stage, where whole fuel element burning occurs, consists of concentric fluidized beds where high heat transfer rates and reliable temperature control are required for the highly exothermic graphite combustion reaction. The second-stage fluidized bed, located above the first stage, provides additional residence time for combustion of graphite particles released from the surface of burning Rover elements. Jet grinders are used to decrease the amount of uranium and niobium oxide retained in the fluidized bed.

Pilot-plant experiments have shown the concentric-bed burner to have the following processing capabilities: (1) graphite combustion efficiencies greater than 95 percent, (2) graphite combustion rates greater than the required plant rate of $16 \mathrm{kilograms} / \mathrm{hr} / \mathrm{ft}^{2}$ of inner bed cross-sectional area, and (3) recovery of essentially all uranium from the fluidized bed by elutriation. The final product elutriated from the fluidized bed contains, in addition to the desired $\mathrm{U}_{3} \mathrm{O}_{8}$ product, some nitric-acid insoluble uranium-niobium compounds, unburned particulate graphite, niobium oxide $\left(\mathrm{Nb}_{2} \mathrm{O}_{5}\right)$, and small amounts of alumina. 


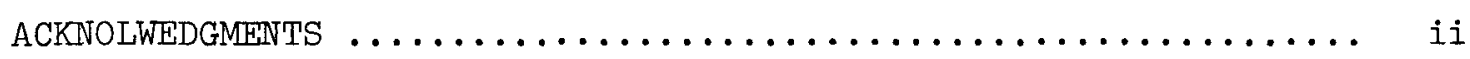

ABSTRACT $\ldots \ldots \ldots \ldots \ldots \ldots \ldots \ldots \ldots \ldots \ldots \ldots \ldots \ldots \ldots \ldots \ldots \ldots \ldots \ldots \ldots \ldots \ldots \ldots$

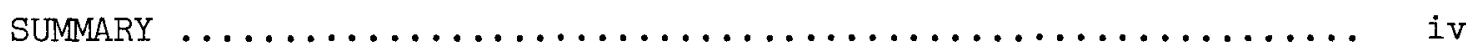

I. INTRODUCTION $\ldots \ldots \ldots \ldots \ldots \ldots \ldots \ldots \ldots \ldots \ldots \ldots \ldots \ldots$

II. PROCESS REQUIREMENTS $\ldots \ldots \ldots \ldots \ldots \ldots \ldots \ldots \ldots \ldots \ldots \ldots \ldots$

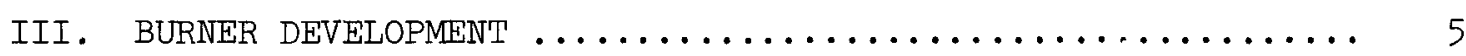

IV. EXPERIMENTAL WORK $\ldots \ldots \ldots \ldots \ldots \ldots \ldots \ldots \ldots \ldots \ldots \ldots \ldots \ldots$

1. BURNER RELIABILITY $\ldots \ldots \ldots \ldots \ldots \ldots \ldots \ldots \ldots \ldots \ldots \ldots \ldots \ldots \ldots \ldots \ldots$

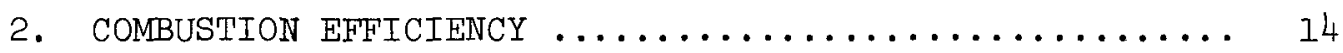

3. URANIUM CONCENTRATION IN THE BURNER ............ 22

4. NIOBIUM CONCENTRATION IN THE BURNER ............ 29

V. CONCLUSIONS $\ldots \ldots \ldots \ldots \ldots \ldots \ldots \ldots \ldots \ldots \ldots \ldots \ldots \ldots \ldots \ldots \ldots \ldots$

VI. FUTURE DEVELOPMENT STUDIES $\ldots \ldots \ldots \ldots \ldots \ldots \ldots \ldots \ldots \ldots \ldots \ldots$

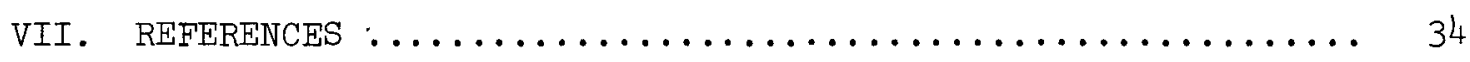
APPENDIX

1. TWO-STAGE CONCENTRIC FLUIDIZED-BED BURNER ........ 35

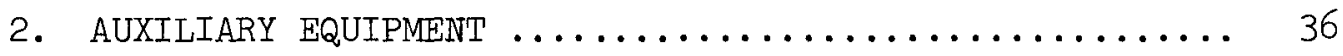

FIGURES

1. Graphite Fuels Pilot Plant-Combustion Process Flowsheet ... 5

2. Evolution of the Graphite Fuels Burner ............. 6

3. Single-Stage Fluidized-Bed Burner $\ldots \ldots \ldots \ldots \ldots \ldots \ldots \ldots$. 7

4. Two-Stage Fluidized-Bed Burner ................... 9

5. Two-Stage Concentric Fluidized-Bed Burner ............ II

6. Effect of First-Stage Oxygen Concentration on Combustion Efficiency 
7. Effect of Second-Stage Bed Height on Combustion

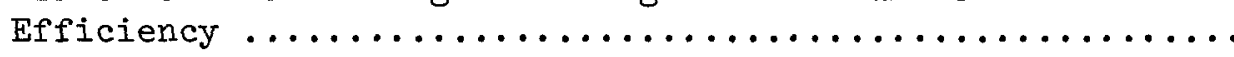

8. Effect of Nominal Bed Temperature on Uranium Retention in Fluidized Alumina Bed (Miniburner Results) ...

9. Uranium Retention in Fluidized Alumina Bed (Graphite

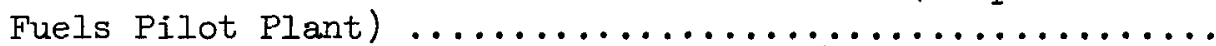

10. Nitric Acid-Insoluble Uranium Concentration in GFPP

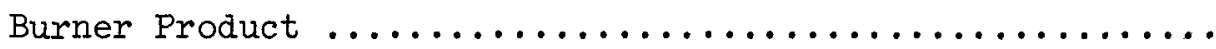

11. Effect of Jet Grinding on $\mathrm{HNO}_{3}$-Insoluble Uranium

Formation in GFPP Burner Product (Initial Fluidized

Bed Contained 15 Weight Percent $\mathrm{HNO}_{3}$-Insoluble Uranium) ...

12. Niobium Retention in Fluidized Alumina Bed (Graphite

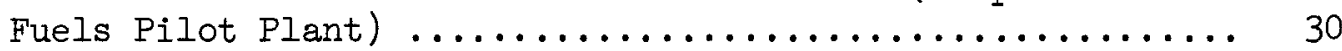

13. Jet Grinder Design Used in Graphite Fuels Burner ........ 38

TABLES

I. Summary of Run Conditions in Two-Stage Fluidized-Bed Burner

II. Summary of Run Results in Two-Stage Fluidized-Bed

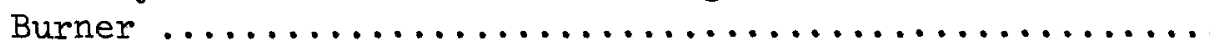

III. Summary of Run Conditions in the Two-Stage Concentric

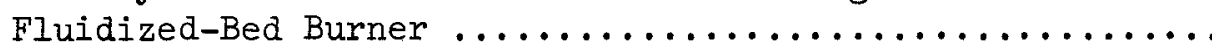

IV. Summary of Run Results Using the Two-Stage Concentric

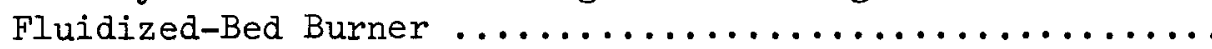




\section{INTRODUCFION}

Pilot-plant development of a fluidized-bed combustion process for separating uranium from spent graphite-matrix nuclear fuels has been in progress since January 1966 at the Idaho Chemical Processing Plant (ICPP). This unique combustion process is required because graphite, unlike the metallic cladding of the more conventional nuclear fuels, is not readily dissolved in common inorganic acids. As the graphite matrix is removed by combustion, the uranium and other metals are converted to their oxides. Dissolution of the resulting uranium oxide, $\mathrm{U}_{3} \mathrm{O}_{8}$, completes the burnleach headend process. The uranium is separated from fission products and other impurities by conventional solvent extraction.

The development effort at ICPP has been specifically oriented toward the reprocessing of spent Rover fuel elements (used in nuclear rocket engines); however, the concepts developed are applicable to graphite-matrix fuels used in the High Temperature Gas-Cooled Power Reactors, e.g., the Peach Bottom and Ft. St. Vrain Reactors (I). The description of Rover fuel which follows is necessarily incomplete because the exact composition is classified. The fuel consists of uranium dicarbide microspheres coated with pyrolytic carbon dispersed in a graphite matrix. A protective coating of niobium carbide is present on some of the surfaces of the fuel elements. Although aluminum or stainless steel orifices are present in some elements, there are only three constituents of consequence to the combustion process: uranium, niobium, and carbon.

The first step in any reprocessing scheme for graphite-matrix fuels is the separation of the heavy metals from the graphite. Process development studies, which were initiated at Oak Ridge National Laboratory (2) and Brookhaven National Laboratory $(3)$, and continued at the $\operatorname{ICPP}(4,5,6,7,8)$, indicated that this separation is best accomplished by combustion of the fuel in a fluidized bed. The high heat transfer rates from fluidized beds made this medium a logical choice for removal of the heat generated by the highly exothermic combustion reactions of graphite, uranium carbide, and niobium carbide.

The processing concept resulting from these early studies included: (1) crushing or chopping the fuel, (2) burning the fuel in a fluidized bed of inert alumina, (3) removing the solids mixture from the burner, (4) leaching uranium from the bed material, (5) separating the leachate from the inert alumina, (6) recovering the uranium from the leachate by solvent extraction, (7) washing the alumina, (8) drying the alumina, and (9) recycling the alumina to the fluidized bed.

The ICPP Rover fuels development program, which followed these initial studies, focused on reducing the number of processing steps to give a minimum-cost, easy-to-operate, processing facility. The only vital processing steps required for uranium recovery are: (1) combustion of the fuel to remove the graphite matrix, (2) dissolution of the uranium 
oxide ash, and (3) solvent extraction recovery of the uranium. Development studies at ICPP established the feasibility of two processsimplifying concepts: ( $(1)$ whole fuel element burning and (2) separation of the solid combustion products $\left(\mathrm{U}_{3} \mathrm{O}_{8}\right.$ and $\left.\mathrm{Nb}_{2} \mathrm{O}_{5}\right)$ from the inert alumina bed by elutriation. Burning whole fuel elements reduces the handling steps required prior to processing and eliminates the problem of containing the radioactive dust generated by crushing or breaking the fuel elements. Separation by elutriation, which is an inherently simple operation, eliminates much of the solids handling equipment required in other separation techniques. The elutriated uranium oxide particles enter the dissolution phase of the headend process for conversion to uranyl nitrate prior to solvent extraction.

A detailed description of the auxiliary equipment associated with the pilot-plant fluidized-bed burner described in this report is given in IN-118I(4). However, the burner described in IN-I18I has been significantly improved and is described in detail in this report. The dissolution system for Rover fuels processing has not been defined and will only be mentioned incidental to the description of the fluidizedbed combustion process.

The purpose of this report is to present a complete account of the development of the process concepts and equipment associated with the fluidized-bed combustion process for Rover fuels. This information is presented in essentially chronological order and details many technical aspects of the development work. Summaries are included after each major section of the report to provide the reader with a more concise account of the accomplishments. 


\section{PROCESS REQUIREMENTS}

The fluidized-bed combustion process developed at ICPP for Rover fuels involves the following concepts: (1) charging of whole fuel elements to a fluidized bed of inert alumina particles, (2) combustion of essentially all carbon, (3) oxidation of uranium and niobium carbides, and (4) elutriation of uranium and niobium oxides from the burner.

Either whole Rover elements or fuel pieces are charged to the alumina bed which is fluidized by an oxygen-rich gas stream. Significant reactions within the fluidized bed are:

$$
\begin{gathered}
\mathrm{C}(\mathrm{s})+\mathrm{O}_{2}(\mathrm{~g}) \longrightarrow \mathrm{CO}_{2}(\mathrm{~g}) \\
\mathrm{C}(\mathrm{s})+\mathrm{I} / 2 \mathrm{O}_{2}(\mathrm{~g}) \longrightarrow \mathrm{CO}(\mathrm{g}) \\
\mathrm{CO}(\mathrm{g})+1 / 2 \mathrm{O}_{2}(\mathrm{~g}) \longrightarrow \mathrm{CO}_{2}(\mathrm{~g}) \\
3 \mathrm{UC}_{2}(\mathrm{~s})+10 \mathrm{O}_{2}(\mathrm{~g}) \longrightarrow \mathrm{U}_{3} \mathrm{O}_{8}(\mathrm{~s})+6 \mathrm{CO}_{2}(\mathrm{~g}) \\
2 \mathrm{NbC}(\mathrm{s})+9 / 2 \mathrm{O}_{2}(\mathrm{~g}) \longrightarrow \mathrm{Nb}_{2} \mathrm{O}_{5}(\mathrm{~s})+2 \mathrm{CO}_{2}(\mathrm{~g})
\end{gathered}
$$

Carbon, present both as the matrix material and as an external coating on the uranium dicarbide microspheres, is the major constituent of Rover fuels. To minimize the solids handing requirements downstream of the headend process, a minimum combustion efficiency of 95 percent is a process requirement. Early studies indicated that acceptable combustion rates could be obtained at temperatures in excess of $1300^{\circ} \mathrm{F}$. Examination of bed material and partially burned fuel elements revealed that, while the bulk of the combustion apparently occurs at the surface of the burning element, particles of unreacted graphite are released from the fuel surface and migrate upward in the bed. Therefore, high combustion efficiencies are also dependent upon adequately long graphite particle retention times.

The oxidation of uranium dicarbide to uranium oxide reaches completion at the conditions necessary for high graphite combustion rates. Development studies at ICPP also revealed that the uranium oxide particles formed during oxidation of the microspheres were of a consistently small size $(90 \%$ less than $45 \mu)$. Calculations showed that these $\mathrm{U}_{3} \mathrm{O}_{8}$ particles could be separated from the bed material by elutriation. Refractory grade alumina was chosen as the bed material because of its high melting point, resistance to attrition, and chemical inertness. The alumina size range (210 to $420 \mu$ ) was selected to give high heat transfer rates 
consistent with negligible elutriation from the burner. Satisfactory operation of the combustion process requires that the uranium concentration in the bed be controlled so that the concentration does not constitute a criticality hazard or reduce the quality of fluidization. Studies showed that jet grinders, which increase the attrition and subsequent elutriation rates of $\mathrm{U}_{3} \mathrm{O}_{8}$, are necessary for uranium concentration control in the fluidized bed.

Niobium carbide, which is present on some surfaces of Rover fuel elements, undergoes in situ oxidation to form large, irregular $\mathrm{Nb}_{2} \mathrm{O}_{5}$ flakes. The minimization of the niobium concentration in the fluidized bed is a process requirement because niobium reacts with uranium to form $\mathrm{HNO}_{3}$-insoluble compounds and high $\mathrm{Nb}_{2} \mathrm{O}_{5}$ concentrations in the burner will degrade the quality of fluidization. Early indications were that grinding in the fluidized bed would be adequate to reduce these flakes to elutriable size particles; however, jet grinders were found necessary to increase the $\mathrm{Nb}_{2} \mathrm{O}_{5}$ attrition rate.

A further requirement of the Rover fuels combustion process is high heat transfer rates from the burner and good temperature control within the burner. Fluidized-bed temperatures greater than $1300^{\circ} \mathrm{F}$ are necessary to obtain combustion rates consistent with the desired Rover fuels processing rates; however, the probability of loss of integrity of the burner vessel must be minimized to avoid the release of radioactive contamination to the environment. Containment reliability requires that fluidized-bed temperatures not greatly exceed the level necessary for adequate processing rates. The highly exothermic oxidation reactions and the need to maintain fluidized-bed temperatures within a relatively narrow range require the burner equipment to rapidly transfer heat away from the reaction zones.

Summary - Process Requirements

Requirements for the fluidized-bed burning and elutriation processes are: (I) combustion of at least 95 percent of the matrix graphite and pyrolytic carbon, (2) conversion of the uranium dicarbide microspheres and niobium carbide to elutriable particles by oxidation and attrition, (3) negligible attrition and elutriation of the inert bed material $(\alpha$ - alumina), and (4) adequate heat dissipation for control of bed temperatures. If "steady-state" conditions can be achieved, all of the uranium and niobium charged to the burner will be elutriated in the burner off-gas. The amount of alumina and unburned carbon carried overhead with the $\mathrm{U}_{3} \mathrm{O}_{8}$ product must be minimized. 


\section{BURNER DEVELOPMENT}

The fluidized-bed burner segment of the Graphite Fuels Pilot Plant (GFPP), shown in Figure 1 , was constructed to permit studies of the combustion process. The burner and leaching equipment, located on two adjacent modules, can be operated independently or simultaneously.

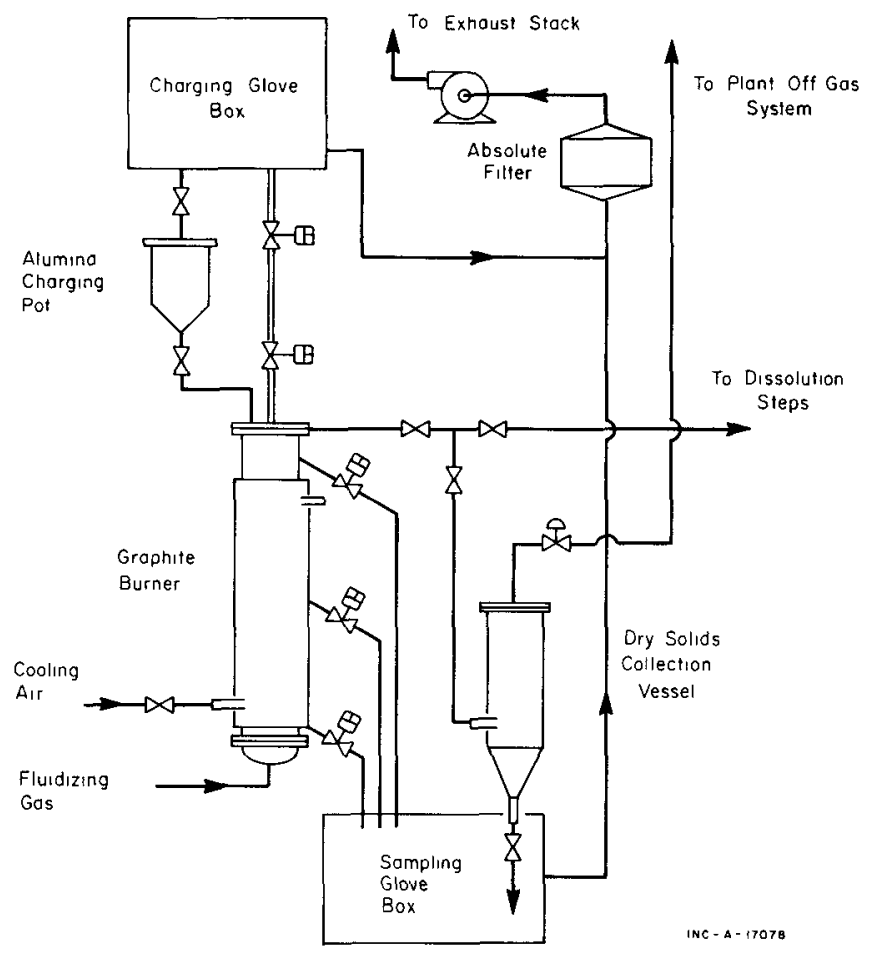

FIGURE 1

Graphite Fuels Pilot Plant-Combustion Process Flowsheet

Major components of the burner module are a fluidized bed for burning the fuel and a dry product collection system for filtering and retaining particulates from the burner off-gas. The dry product collection system is bypassed when direct introduction of the burner product into the leaching equipment is desired. Application of the process requirements described in the preceding section resulted in the evolution of a series of fluidized-bed burner designs. The three major designs in this progressive development are shown in Figure 2. To limit the throughput of the pilot-plant burner, a primary vessel diameter of four inches was selected. The length of the Rover fuel elements (52 inches) dictated the height of the initial burner. The need for longer graphite particle retention times to increase the combustion efficiency and the need for increased heat transfer rates led to the two subsequent major modifications of the burner design. 


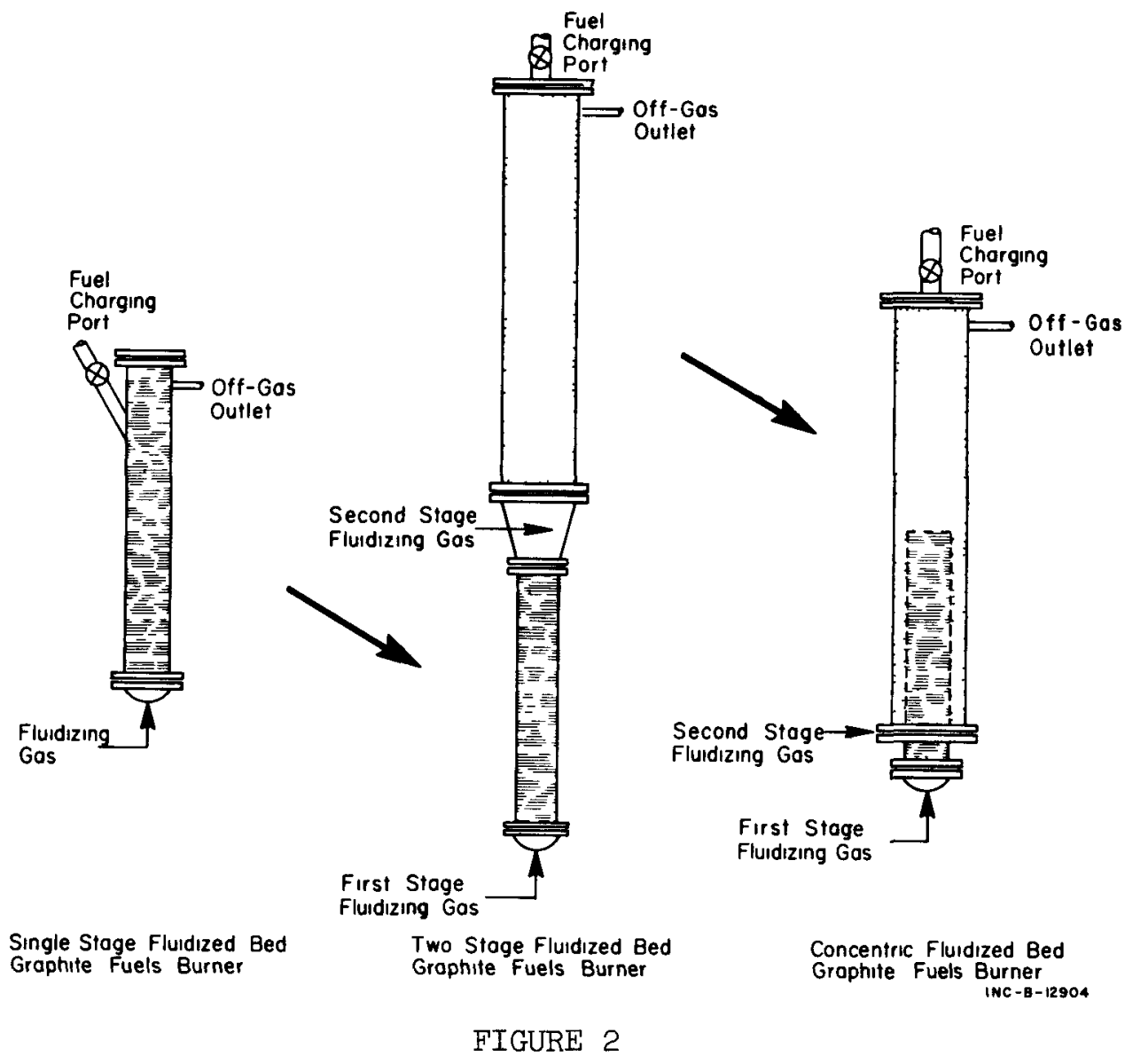

Evolution of the Graphite Fuels Burner

The first burner, a 4-inch diameter by 4-1/2-foot long unit (see Figure 3) called the single-stage fluidized-bed burner, was constructed primarily to test the feasibility of separating the uranium and niobium oxides from the inert fluidized-bed material by elutriation. The operating conditions chosen for the first scoping studies were: (I) a nominal bed temperature of 1300 to $1350^{\circ} \mathrm{F}$, (2) a superficial fluidizing velocity of $1.0 \mathrm{ft} / \mathrm{sec}$, and (3) a fluidizing-gas composition of 60 percent oxygen, 40 percent nitrogen. Solids $\left(\mathrm{U}_{3} \mathrm{O}_{8}, \mathrm{Nb}_{2} \mathrm{O}_{5}\right.$, and small amounts of alumina and unburned carbon) elutriated from the burner were retained in the dry product collection system. Segments of Rover fuel elements were charged to the burner. 


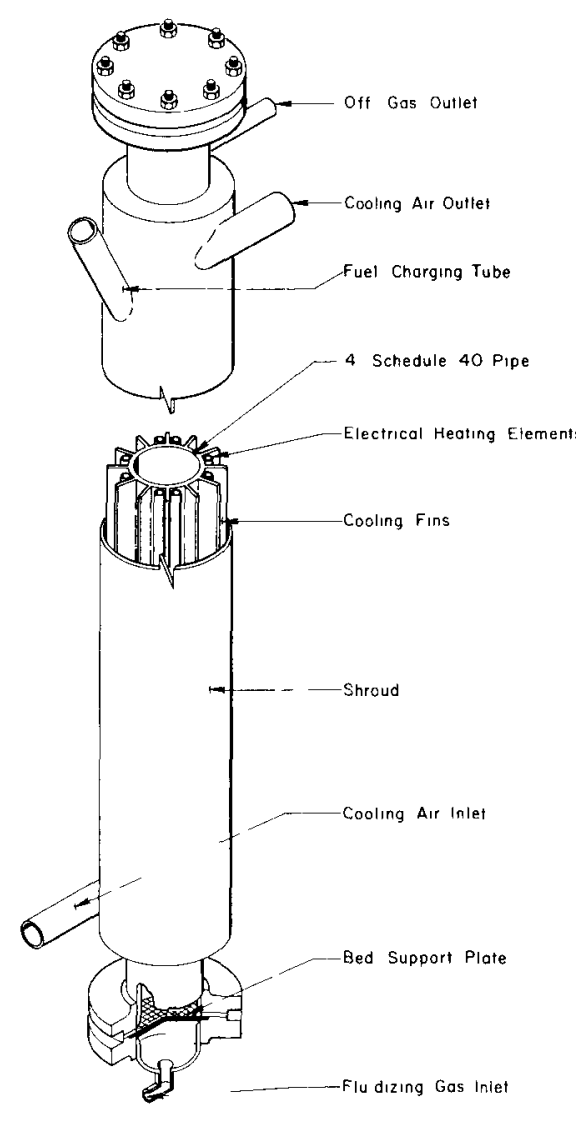

FIGURE 3

Single-Stage Fluidized-Bed Burner

These scoping tests showed that $\mathrm{U}_{3} \mathrm{O}_{8}$ particles could be separated from the alumina bed material by elutriation and that the alumina elutriation rate was less than 0.1 percent of the total bed weight per 24 hours of operation. The graphite combustion efficiencies realized during these tests, however, were only 65 percent. The remaining graphite was elutriated from the burner as particles less than $150 \mu$ in diameter. Although the general operability of the single-stage fluidized-bed burner was satisfactory, the need for improved combustion efficiencies was apparent.

The two-stage fluidized-bed burner, shown schematically in Figure 4, was designed to increase the particle residence time and oxygen availability within the fluidized bed, to increase the combustion efficiency. A detailed description of this fluidized-bed burner and much of the auxiliary equipment included in the present pilot plant is given in IN-1181. Examination of fuel pieces removed from the single-stage burner indicated that most of the oxygen reacted in the lower one-third of the fluidized bed. To correct this situation, a six-inch diameter by 
9' 2 " long "second stage" was mated to the top of the existing fourinch diameter single-stage burner. A fuel charging tube was added to allow a fuel element to reach the lower 4-inch section or first-stage burner. A larger tube, concentric to the fuel charging tube, formed an annular preheater through which secondary fluidizing gas was fed into the bed at a point just above the lower stage of the burner. Perforated baffle plates were added to the second stage to reduce the intensity of "slugging" anticipated from the increased L/D ratio.

The combustion process within the two-stage fluidized-bed burner may be envisioned as follows. Fuel elements commence burning in the lower-stage burner; particles of unreacted graphite or uranium dicarbide, released from the fuel surface in the lower-stage burner, migrate upward to the bottom of the second-stage burner. The secondary fluidizing-gas stream (pure oxygen) provides additional $\mathrm{O}_{2}$ for combustion.

Studies using the two-stage fluidized-bed burner were made to define the effect of (1) superficial fluidizing velocity, (2) fluidizing-gas composition, and (3) second-stage bed height on combustion efficiency. Results from these studies showed that combustion efficiencies greater than 95 percent could be consistently obtained in the two-stage burner. The maximum combustion efficiency attained (98 percent) was at the following conditions: 100 percent oxygen feed to first stage, a mean bed temperature of 1400 to $1500^{\circ} \mathrm{F}$, and a second-stage bed height of seven feet.

Localized temperature excursions occurred frequently which, on occasion, resulted in the formation of alumina clinkers and damage to the burner vessel. Portions of the baffled-tube assembly, the fuel support grid, and areas on the wall of the first-stage burner were warped or melted through as a result of high temperatures.

In addition to the temperature excursions, which occurred as isolated incidents, the temperatures within the first-stage burner were not typical of well-mixed fluidized beds. A well-mixed fluidized bed (non-baffled with low L/D ratio) generally has temperature differentials less than $5^{\circ} \mathrm{F}$ for a comparable heat duty $(9)$. The high L/D ratio of the two-stage unit caused slugging and a reduction in heat transfer rates in the first stage of the burner. Reduced heat transfer coupled with localized heat generation characteristic of whole fuel element burning, caused temperature differentials of 100 to $150^{\circ} \mathrm{F}$ to occur frequently in the first-stage burner.

The presence of perforated baffles in the second stage of the burner effectively increased the heat transfer capacity by reducing the severity of slugging at the high $L / D$ ratios $(a)$. This factor, combined with the more uniform heat generation characteristic of particulate graphite combustion, resulted in smaller temperature differentials ( 20 to $50^{\circ} \mathrm{F}$ ) in the second stage.

The thermal instabilities in the first-stage burner led to a lossof-containment incident; this dictated the need for redesign of the graphite burner. The two-stage burner was redesigned to increase first-

(a) See pages $25-27$ in Reference 8 . 


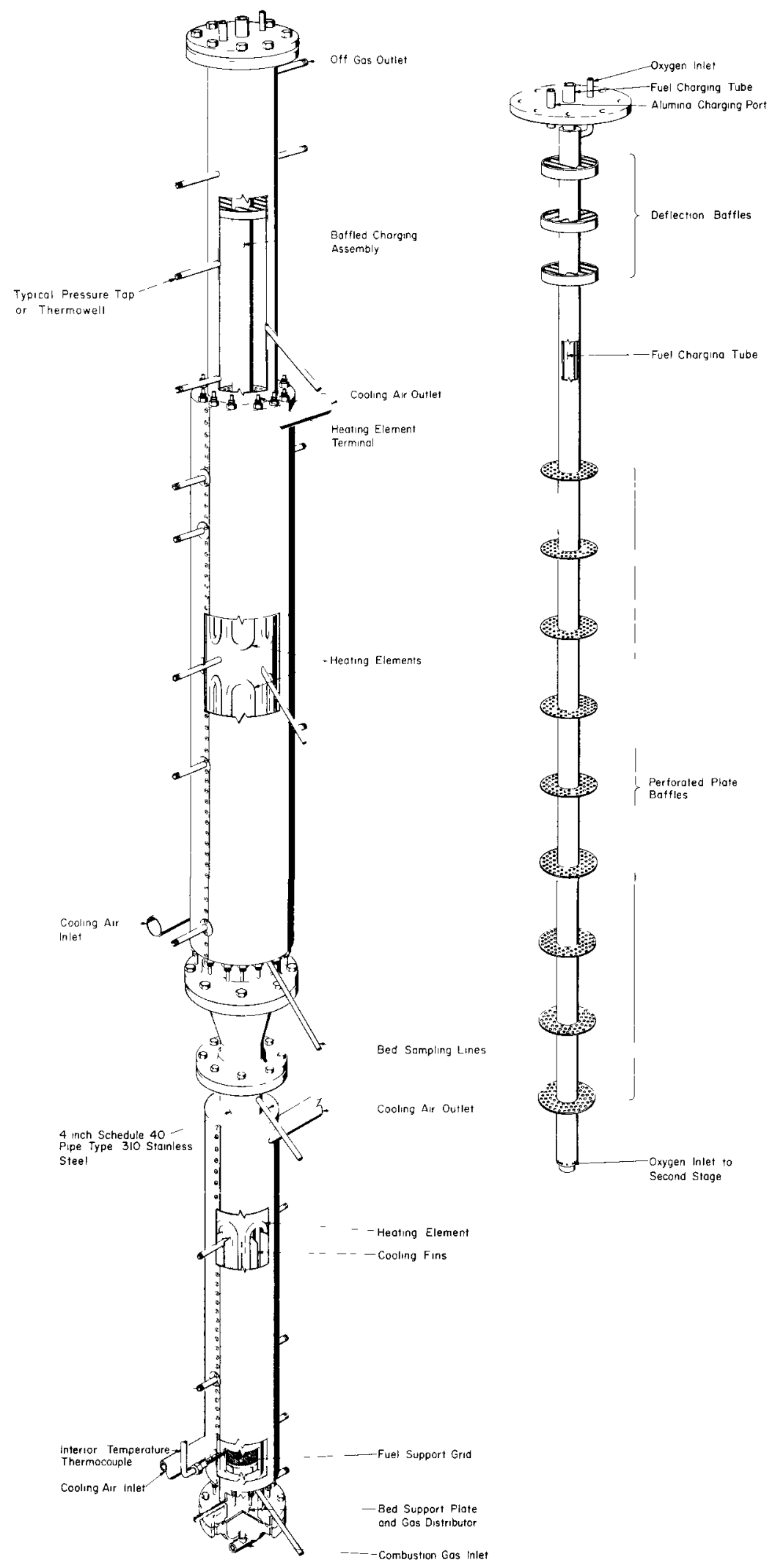

FIGURE 4

Two-Stage Fluidized-Bed Burner 
stage heat transfer rates. Since burner reliability was of primary importance, the burner was also designed on the basis of double containment, i.e., even if a melt-through of the primary containment occurred, radioactive contamination would not be released.

The new burner design, the concentric-bed fluidized-bed burner, is shown schematically in Figure 5. A four-inch diameter, 4-1/2-foot long first-stage burner is located concentrically inside a six-inch diameter vessel which extends $8-1 / 2$ feet above the top of the first stage. Fluidized beds are contained in the four-inch diameter first stage, the surrounding annular space, and in the six-inch diameter section above the first stage. The wall of the upper two feet of the first-stage burner is slotted to allow particle mixing between the annular and inner beds.

The concentric fluidized-bed design was proposed on the basis of potential increased heat transfer rates from the wall of the inner firststage burner. The outer wall of the first-stage burner in the earlier two-stage fluidized-bed burner was cooled by forced-air convection; this proved to be adequate under normal conditions but inadequate in the event of a temperature excursion. Substitution of the annular bed for the forced convection system was expected to increase the heat transfer coefficients at the first-stage wall by an order of magnitude. The annular fluidized bed provides the added advantage of secondary containment should a melt-through of the inner vessel occur.

Tests conducted with a six-inch diameter glass column containing the actual four-inch diameter inner bed further showed that increased heat transfer could also be expected from particle mixing between the inner and annular beds. The intensity of slugging in the inner bed was greatly reduced in the upper two feet due to the transfer of gas and particles between the inner and annular beds.

The anticipated improvement in heat transfer using the concentric fluidized-bed burner has been realized. The concentric-bed design has proved superior to the original two-stage burner with respect to heat transfer and temperature control. No temperature excursions have occurred in any of the experiments. Temperature differentials within the first stage have ranged from a normal spread of 25 to $45^{\circ} \mathrm{F}$ to a maximum spread of $75^{\circ} \mathrm{F}$ at a fuel-burning rate 10 percent higher than the maximum burning rate in the two-stage burner. At fuel charging rates equivalent to two times the rate proposed for the Rover plant burner ( 16 kilograms of carbon per hour per square foot of inner-bed crosssectional area), the temperature spread increased to $100^{\circ} \mathrm{F}$. This is still superior to the temperature spreads of 100 to $150^{\circ} \mathrm{F}$ observed frequently in the first stage of the two-stage burner at lower combustion rates.

The current burner design provides operational stability over a much wider range of fluidizing velocities than the earlier two-stage design. Fluidization tests conducted in a six-inch diameter glass column have shown that the annular bed can be fluidized without severe slugging at superficial fluidizing velocities up to 2.5 feet per second; the four-inch diameter inner bed can be fluidized at superficial 


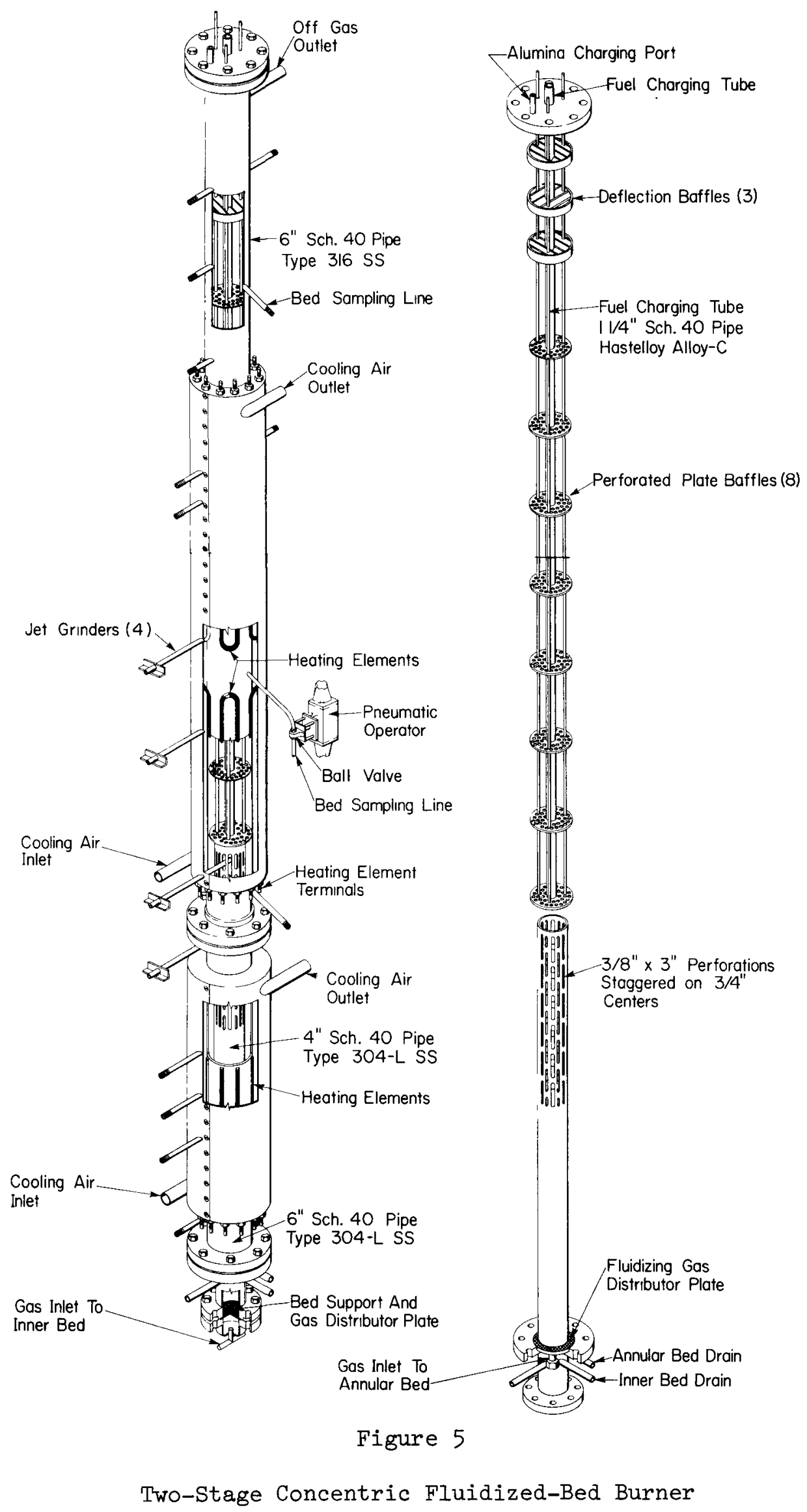


velocities up to 2.0 feet per second without serious degradation of the quality of fluidization. These tests were conducted at a fluidized-bed $L / D$ ratio greater than 10 .

The original concentric fluidized-bed burner was essentially a "telescoped" version of the earlier two-stage burner, because the $9^{\prime} 2^{\prime \prime}$ long six-inch diameter second stage of the earlier burner was used as the outer six-inch vessel. This was done to make maximum use of equipment from the two-stage burner. However, operation of the concentric-bed burner revealed that the second-stage bed height (reduced from 7 to 2.5 feet) resulted in a decrease in the graphite combustion efficiency from 98 to 90 percent. Therefore, a 3-1/2-foot, six-inch diameter spool piece was added to the second-stage vessel. Combustion efficiencies greater than 96 percent have been realized as a result of the increase in second-stage bed height to six feet.

A detailed description of the concentric fluidized-bed burner is included in the Appendix. Description of several elements of the pilot-plant burner system, e.g., sampling and charging glove boxes-have been omitted from this report, as they have been adequately described in IN-1181. These systems have remained unchanged in the transition from the earlier two-stage burner to the present concentric fluidizedbed burner. Descriptions of the miniburner, a two-inch diameter fluidized-bed, and various glass columns used in the development program are also included in the Appendix.

Summary - Burner Development

The fluidized-bed burner for the Rover fuels combustion process has undergone two major design modifications during the development program. The initial single-stage burner was designed primarily to determine the feasibility of separating the uranium and niobium oxides from the alumina bed by elutriation. These studies proved elutriation to be feasible; however, the graphite combustion efficiencies were much less than the required 95 percent.

The two-stage burner was designed to increase the graphite particle residence time and oxygen availability, thereby increasing combustion efficiency. The burner consisted of a 9 ' 2 " long "second stage" mated to the top of the original four-inch diameter single-stage burner. Combustion efficiencies greater than the required 95 percent were consistently obtained; however, burner operation was extremely unstable, and temperature excursions in the first-stage burner eventually resulted in a loss-of-containment incident.

The current design, the two-stage concentric-bed burner, was designed to improve heat transfer rates from the wall of the first-stage burner. Fluidized beds are contained in the four-inch diameter first stage and in the one-inch annulus surrounding the first stage. The six-inch second-stage burner is unchanged from the earlier two-stage design. The concentric-bed design has provided the needed improvement in heat transfer capability and permits stable operation over a much wider range of process variables (e.g., fluidizing velocity, charging rates, $\mathrm{O}_{2}$ concentrations) than the earlier two-stage design. Further, the annular fluidized bed provides the added advantage of secondary containment should a melt through of the inner vessel occur. 


\section{EXPERIMENTAL WORK}

\section{BURNER RELIABILITY}

The reliability of the equipment directly associated with the fluidized-bed combustion process has been a continuing concern during the development program. High temperatures (up to $1500^{\circ} \mathrm{F}$ ) combined with high rates of heat generation within the burner place unusually severe demands on the heat transfer capabilities and structural materials of the burner.

The single-stage burner, normally fluidized with a gas stream of 60 percent oxygen and 40 percent nitrogen, did not exhibit temperature control or corrosion problems. A single temperature excursion, caused by a short-term (about 15 minutes) failure of the plant air supply which increased the oxygen concentration to 100 percent, resulted in a bed temperature of $1750^{\circ} \mathrm{F}$. Because the incident was of short duration, the vessel was not damaged.

The two-stage fluidized-bed burner was damaged several times by temperature excursions. Portions of the gas distributor plate, fuel support grid, baffled charging tube assembly, and first-stage burner wall melted in separate incidents as a result of these excursions. The causes of the damage were on occasion traced to the abnormal operating conditions used in statistically designed experiments; however, several of the excursions resulted from process upsets. Experimental observations and theoretical calculations indicate that graphite combustion temperatures at reaction sites far exceed those under which the burner vessel retains its structural integrity.

A distinct disadvantage of the two-stage burner design was inherent in the high L/D ratio required for adequate graphite particle retention times to obtain high combustion efficiencies. Good quality fluidization (absence of slugging) was obtained only within a narrow range of fluidizing velocities ( 0.9 to $1.1 \mathrm{ft} / \mathrm{sec})$. Thus, process upsets could readily degrade the quality of fluidization to a point where a temperature excursion with potential for burner-wall failure could occur.

Further, the forced-air convection cooling system for the first stage of the two-stage burner was not adequate to transfer the heat away from the vessel wall during temperature excursions. A reduction of the oxygen concentration in the fluidizing-gas stream was necessary to control these abrupt increases in temperature. Also, the forcedair convection system could increase the severity of a loss-ofcontainment incident by accelerating the spread of contamination.

The concentric-bed burner is designed to either eliminate or reduce the severity of the two-stage burner limitations mentioned above. Heattransfer rates from the wall of the first-stage burner were increased by the presence of the annular fluidized bed. The annular-bed wall 
provides secondary containment in the event that the inner-bed wall melts through. The range of fluidizing velocities is also increased significantly because of a decrease in the effective L/D ratio. The upper two feet of the first-stage bed are slotted which results in an essentially unrestrained six-inch diameter fluidized bed and a corresponding decrease in the $\mathrm{L} / \mathrm{D}$ ratio.

After 600 hours of operation at process conditions ( 1250 to $1450^{\circ} \mathrm{F}$ at the plant-equivalent fuel charging rate), no temperature excursions have been noted in the concentric-bed fluidized-bed burner. This length of operation corresponds to more than 25 percent of the maximum proposed plant processing campaign (90 days). Corrosion coupons have been installed at several points within the burner and the microstructure of various components of the burner are examined periodically to determine the maximum serviceable life of the equipment. Extensive carbide precipitation has been observed in austenitic stainless steel alloys; therefore, several high temperature, nickel-base alloys are currently being evaluated for plant use.

\section{COMBUSTION EFFICIENCY}

A primary objective in the development of the fluidized-bed combustion process has been to minimize the alumina and graphite particles elutriated from the burner. Solids downstream of the burner increase the problems associated with subsequent dissolution steps. Calculations based on the capacity of the ICPP centrifuge, which has been proposed for the solid-liquid separation following leaching, and the projected plant processing rate showed the minimum acceptable graphite combustion efficiency to be 95 percent.

The initial single-stage fluidized-bed burner was operated at the following conditions: (1) a nominal bed temperature of 1300 to $1350^{\circ} \mathrm{F}$, (2) a superficial fluidizing velocity of $1.0 \mathrm{ft} / \mathrm{sec}$, and (3) a fluidizing-gas composition of 60 percent oxygen, 40 percent nitrogen. Fuel was charged to the burner in segments rather than whole elements.

A combustion efficiency of only 65 percent was realized during these tests. Examination of partially-burned fuel segments indicated that most of the burning occurred in the lower one-third of the fluidized bed. Thus, the low combustion efficiency was due mainly to insufficient oxygen in the upper portion of the fluidized bed.

The two-stage fluidized-bed concept evolved from the need for increased oxygen availability and increased residence time of elutriable graphite particles. The new design permitted the introduction of pure oxygen at a point just above the top of the first-stage burner. The height of the six-inch diameter second-stage burner (nine feet) was sufficient to define the effect of bed height on combustion efficiency. Perforated baffle plates were installed in the second stage to minimize slugging. 
Experiments in the two-stage burner were made to define the effect of (1) fluidizing-gas composition, (2) second-stage bed height, and (3) superficial fluidizing velocity on combustion efficiency. A summary of run conditions in the two-stage unit is shown in Table I; Table IJ contains the results of these tests. These results show that combustion efficiencies greater than 95 percent could be consistently obtained.

Graphite combustion efficiency increased significantly with increasing oxygen concentrations in the first-stage fluidizing gas (see Figure 6). A maximum combustion efficiency of 98 percent was obtained by increasing the oxygen concentration in the first-stage fluidizing gas to 100 percent and operating at a relatively high nominal bed temperature (1400 to $\left.1475^{\circ} \mathrm{F}\right)$. The increased combustion rates, caused large temperature differentials within the first-stage burner (as high as $300^{\circ} \mathrm{F}$ ).

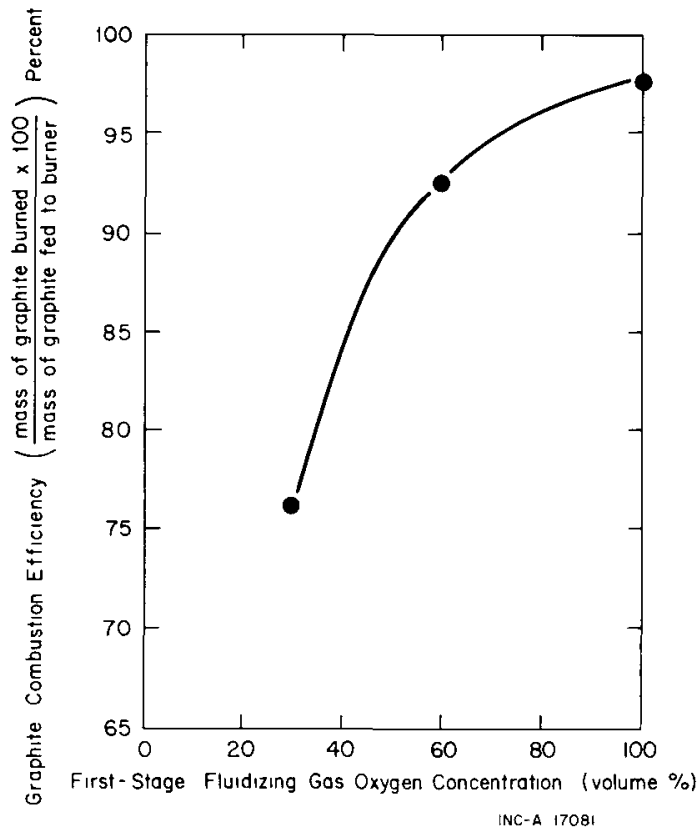

FIGURE 6

Effect of First-Stage Oxygen Concentration on Combustion Efficiency

Experimental and theoretical studies were conducted to determine the effect of second-stage bed height on graphite combustion efficiency. It is desirable to minimize the total bed height, consistent with the desired 95 percent combustion efficiency, to decrease the pressure drop through the fluidized bed. Any reduction in operating pressure is desirable from a safety standpoint when processing irradiated fuef. Calculations, based on the elutriation model of Wen and Hashinger (io) and the graphite combustion rate data of E. Lopez-Menchero, et al. (12), predicted that combustion efficiencies greater than $95 \%$ could be obtained at second-stage bed heights of two to three feet. Experimental studies showed that combustion efficiencies greater than 95 percent could be obtained with bed heights ranging from one to seven feet; however, for bed heights less than five feet, combustion occurred in the vapor space 


\section{TABLE I}

Summary of Run Conditions in

Two-Stage Fluidized-Bed Burner(I)

\begin{tabular}{|c|c|c|c|c|c|c|c|c|}
\hline Run Number & 1 & 2 & 3 & 4 & 5 & 6 & 7 & 8 \\
\hline Run Duration, Hours & 21 & 6 & 7 & $\ldots-(2)$ & 8 & 8 & 7 & $-(3)$ \\
\hline $\begin{array}{l}\text { Nominal Bed } \\
\text { Temperature, of }\end{array}$ & 1300 & 1475 & 1300 & 1300 & 1350 & 1300 & $1200-1400$ & --- \\
\hline $\begin{array}{l}\text { Fluidizing } \\
\text { Velocity, ft/sec } \\
\text { First Stage } \\
\text { Second Stage }\end{array}$ & $\begin{array}{l}0.8 \\
1.0\end{array}$ & $\begin{array}{l}0.8 \\
1.0\end{array}$ & $\begin{array}{l}0.8 \\
1.0\end{array}$ & $\begin{array}{l}1.0 \\
1.0\end{array}$ & $\begin{array}{l}1.0 \\
1.0\end{array}$ & $\begin{array}{l}1.0 \\
1.0\end{array}$ & $\begin{array}{l}1.0 \\
1.0\end{array}$ & $\begin{array}{l}1.25 \\
1.0\end{array}$ \\
\hline $\begin{array}{l}\text { Fluidizing-Gas Feed } \\
\text { First Stage } \% \mathrm{O}_{2} \\
\text { Second Stage } \mathrm{\% O}_{2}\end{array}$ & $\begin{array}{r}30 \\
100\end{array}$ & $\begin{array}{l}100 \\
100\end{array}$ & $\begin{array}{r}60 \\
100\end{array}$ & $\begin{array}{l}100 \\
100\end{array}$ & $\begin{array}{l}100 \\
100\end{array}$ & $\begin{array}{l}100 \\
100\end{array}$ & $\begin{array}{c}60-90 \\
100\end{array}$ & $\begin{array}{l}100 \\
100\end{array}$ \\
\hline $\begin{array}{l}\text { Second-Stage } \\
\text { Fluidized-Bed } \\
\text { Height, feet }\end{array}$ & 7 & 7 & 7 & 1 & 5 & 3 & 3 & 7 \\
\hline $\begin{array}{l}\text { Throughput Rate, } \\
\text { (Per unit first- } \\
\text { stage cross sectional } \\
\text { area) kg graphite/hr/ft } 2\end{array}$ & 9.2 & 15.7 & 12.0 & 16.2 & 22.6 & 24.0 & $8.0-16.4$ & --- \\
\hline
\end{tabular}

(1) Uncoated Rover fuel was charged during all reported runs.

(2) High temperatures above fluidized bed forced an early termination of this run.

(3) Burner operating out of control at higher fluidizing velocities; run terminated early. 


\section{TABLE II}

Summary of Run Results in

Two-Stage Fluidized-Bed Burner

\begin{tabular}{|l|c|c|c|c|c|c|c|}
\hline Run Number & 1 & 2 & 3 & 4 & 5 & 6 & 7 \\
\hline $\begin{array}{l}\text { Graphite Combustion } \\
\text { Efficiency, } \\
\text { percent }\end{array}$ & 76 & 98 & 92 & 96 & 95 & 97 & $94-99$ \\
\hline $\begin{array}{l}\text { Uranium concen- } \\
\text { tration in final } \\
\text { bed, weight percent }\end{array}$ & 0.90 & 0.99 & 1.50 & -- & 5.61 & 7.46 & 11.67 \\
\hline $\begin{array}{l}\text { Burner Heat } \\
\text { Generation Rate, } \\
\text { Btu/hr }\end{array}$ & 25,800 & 44,300 & 33,900 & 45,500 & 63,800 & 67,700 & $\begin{array}{c}22,600- \\
46,200\end{array}$ \\
\hline
\end{tabular}

(1) Combustion efficiency equals the weight percent of charged graphite burned in the fluidized bed. 
above the bed (see Figure 7). Vapor space burning (in the freeboard above the bed) could result in damage to exposed metal surfaces. For this reason, a second-stage bed height of five feet was recommended a.s the minimum.

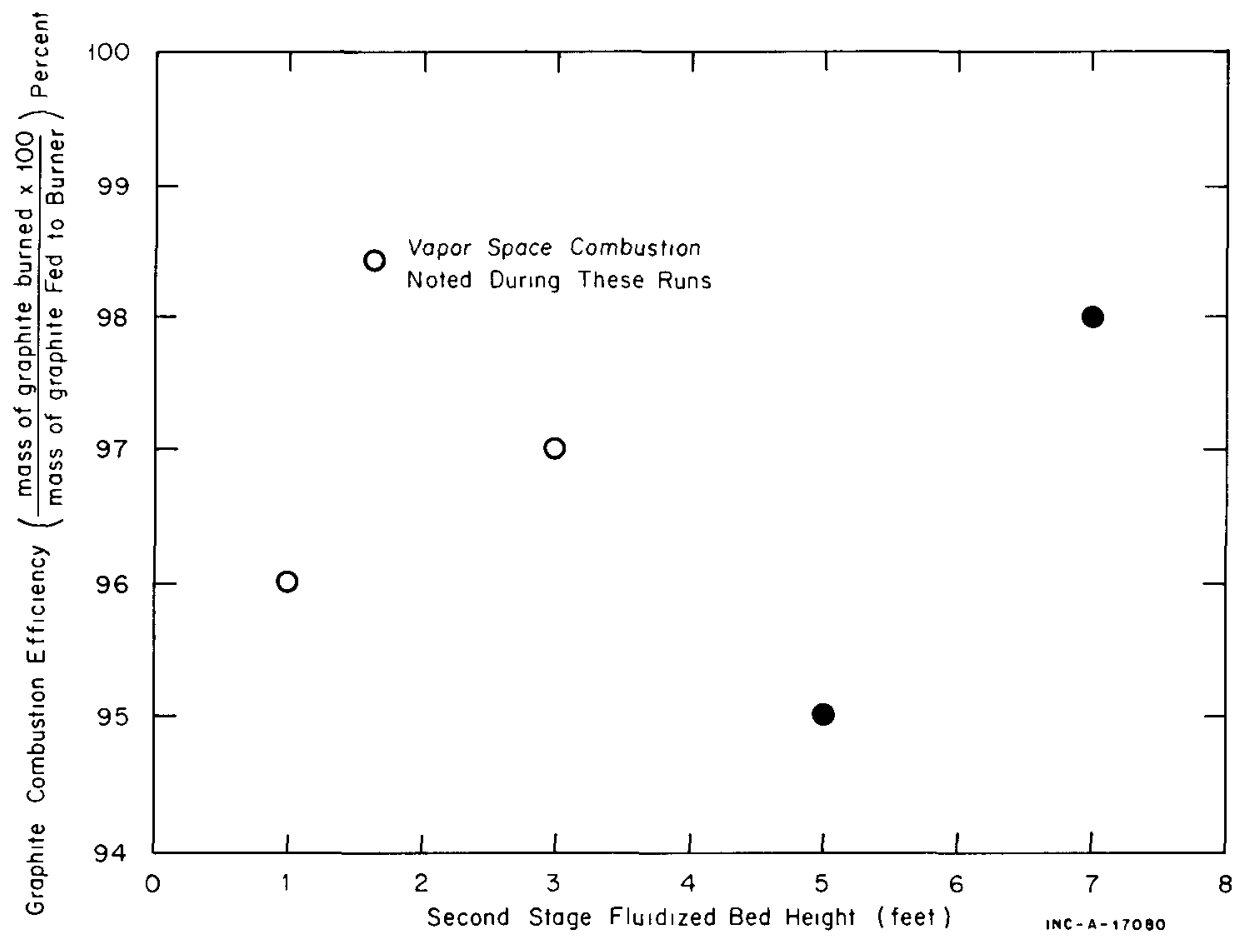

FIGURE 7

Effect of Second-Stage Bed Height on Combustion Efficiency

The high L/D ratio of the two-stage fluidized bed and the bed temperature instabilities limited the range of fluidizing velocities ( 0.9 to $1.1 \mathrm{ft} / \mathrm{sec}$ ) over which a well-fluidized bed could be obtained. Over the narrow range of velocities studied, no significant effect of fluidizing velocity on combustion efficiency was noted.

The two-stage concentric fluidized-bed burner replaced the original two-stage burner primarily because improved heat transfer and burner reliability were required. The concentric-bed design was expected to reduce the bed height required to achieve a specified combustion efficiency because graphite particles could pass through the slotted wall of the inner bed and partially burn while rising through the annular bed to the second stage. The maximum combustion efficiency realized in the original concentric-bed burner was 90 percent. Vapor space burning of graphite particles was noted during runs conducted at high charging rates. This was attributed to the inadequate particle residence time in the second-stage bed (maximum height - 2.5 feet). An increase of the second-stage fluidized-bed height to six feet resulted in combustion efficiencies greater than the required 95 percent. 
A summary of several run conditions and the results of these experiments is shown in Tables III and IV, respectively. Several of the experiments (Runs 1 through 8) conducted in the concentric-bed burner were for a statistical evaluation of the effect of ( 1 ) bed temperature, (2) inner-bed fluidizing velocity, (3) annular-bed fluidizing velocity, and (4) percent oxygen in the inner-bed fluidizing gas on several system responses including combustion efficiency.

The results of these tests showed that the effect of nominal bed temperature is significant (at the 95 percent confidence level). An increase of bed temperature from the low level $\left(1250^{\circ} \mathrm{F}\right)$ to the high level $\left(1400^{\circ} \mathrm{F}\right)$ resulted in a 16.5 percent increase in combustion efficiency. The effect of the other variables was not shown to be significant at the 95 percent confidence level.

Experimental runs conducted subsequent to the burner modifications, which increased the second-stage bed height from 2.5 to 6.0 feet, (Runs 10 and 11 in Tables III and IV) showed that combustion efficiencies greater than 95 percent are attainable. At the proposed plant charging rate, combustion efficiencies greater than 96 percent have been obtained at the following conditions:

(1) Nominal bed temperature $-1450^{\circ} \mathrm{F}$.

(2) 100 percent oxygen in fluidizing gas to both inner and annular beds.

(3) Mean fluidizing velocities (average of inner and annular bed velocities) ranging from 1.05 to $1.25 \mathrm{ft} / \mathrm{sec}$.

Combustion efficiencies greater than the required 95 percent have been attained at higher fluidizing velocities and at a lower inner-bed oxygen concentration ( 80 percent). A combustion efficiency of 96 percent was noted at a fuel charging rate twice the proposed plant rate.

\section{Summary - Combustion Efficiency}

Calculations based on the solids-handling capacity of the ICPP centrifuge showed the minimum acceptable combustion efficiency to be 95 weight percent. Combustion efficiencies of only 65 weight percent in a single-stage burner led to the use of the two-stage burner. Most of the burning occurs in the lower, first-stage burner on the surface of Rover elements; however, particles released from the burning surface migrate upward to the second stage. The second-stage burner provides additional oxygen and increased particle residence times to increase combustion efficiency.

Combustion efficiencies equal. to or greater than the required 95 weight percent have been obtained in the two-stage concentric fluidized bed over the following ranges of operating variables:

(1) Nominal bed temperature - 1400 to $1500^{\circ} \mathrm{F}$.

(2) Fluidizing-gas composition - 80 to 100 percent oxygen to both stages.

(3) Mean fluidizing velocities (average of inner and annular fluidizing velocities) -1.05 to $1.50 \mathrm{ft} / \mathrm{sec}$.

(4) Fuel charging rates - up to $33 \mathrm{kilograms}$ graphite/hr/ft ${ }^{2}$. 
TABLE III

Summary of Run Conditions in the Two-Stage Concentric Fluidized-Bed Burner(I)

\begin{tabular}{|c|c|c|c|c|c|c|c|c|c|c|c|c|c|c|c|}
\hline Run Number & 1 & 2 & 3 & 4 & 5 & 6 & 7 & 8 & 9 & 10 & 11 & 12 & 13 & $14^{(2)}$ & 15 \\
\hline $\begin{array}{l}\text { Run Duration, } \\
\text { Hours }\end{array}$ & 24 & 24 & 24 & 24 & 20 & 20 & 20 & 20 & 72 & 24 & 4 & 4 & 5 & 48 & 52 \\
\hline $\begin{array}{l}\text { Nominal Bed } \\
\text { Temperature, of }\end{array}$ & 1400 & 1400 & 1400 & 1400 & 1400 & 1400 & 1400 & 1400 & $\begin{array}{l}1300- \\
1350\end{array}$ & $\begin{array}{l}1400- \\
1450\end{array}$ & $\begin{array}{l}1400- \\
1450\end{array}$ & $\begin{array}{l}1400- \\
1450\end{array}$ & $\begin{array}{l}1400- \\
1450\end{array}$ & 1450 & 1450 \\
\hline $\begin{array}{l}\text { Fluidizing } \\
\text { Velocity, ft/sec } \\
\text { Inner Bed } \\
\text { Annular Bed } \\
\text { Second Stage }\end{array}$ & $\begin{array}{l}1.0 \\
2.0 \\
1.5\end{array}$ & $\begin{array}{l}1.0 \\
1.5 \\
1.25\end{array}$ & $\begin{array}{l}1.5 \\
2.0 \\
1.75\end{array}$ & $\begin{array}{l}1.5 \\
2.0 \\
1.75\end{array}$ & $\begin{array}{l}1.5 \\
1.5 \\
1.5\end{array}$ & $\begin{array}{l}1.5 \\
1.5 \\
1.5\end{array}$ & $\begin{array}{l}1.0 \\
2.0 \\
1.5\end{array}$ & $\begin{array}{l}1.0 \\
1.5 \\
1.25\end{array}$ & $\begin{array}{l}1.0 \\
1.1 \\
1.05\end{array}$ & $\begin{array}{l}1.0 \\
1.1 \\
1.05\end{array}$ & $\begin{array}{l}1.25 \\
1.50 \\
1.37\end{array}$ & $\begin{array}{l}1.25 \\
1.50 \\
1.37\end{array}$ & $\begin{array}{l}1.25 \\
1.50 \\
1.37\end{array}$ & $\begin{array}{l}1.25 \\
1.50 \\
1.37\end{array}$ & $\begin{array}{l}1.25 \\
1.50 \\
1.37\end{array}$ \\
\hline $\begin{array}{l}\text { Inner-Bed } \\
\text { Fluidizing Gas, } \\
\text { Percent Oxygen }\end{array}$ & 100 & 100 & 100 & 100 & 100 & 100 & 100 & 100 & 70 & 100 & 100 & 100 & 100 & 100 & 100 \\
\hline $\begin{array}{l}\text { Throughput } \\
\text { Rate (per unit } \\
\text { First-stage area) } \\
\text { kg graphite/hr/ft }{ }^{2}\end{array}$ & 14.2 & 18.1 & 16.5 & 16.5 & 15.6 & 14.4 & 14.4 & 14.4 & 15.2 & 15.6 & 21.3 & 25.6 & 33.3 & 13.0 & 13.0 \\
\hline
\end{tabular}

(1) All runs reported were completed after the fluidized-bed height was increased to six feet.

(2) Jet grinders in operation during this run. 


\section{TABLE IV}

Summary of Run Results Using the Two-Stage Concentric Fluidized-Bed Burner

\begin{tabular}{|c|c|c|c|c|c|c|c|c|c|c|c|c|c|c|c|}
\hline Run Number & 1 & 2 & 3 & 4 & 5 & 6 & 7 & 8 & 9 & 10 & 11 & 12 & 13 & 14 & 15 \\
\hline $\begin{array}{l}\text { Graphite Combustion } \\
\text { Efficiency, percent }\end{array}$ & 92 & 96 & 95 & 95 & 93 & 96 & 92 & 94 & 87 & 95 & 91 & 91 & 96 & 95 & 95 \\
\hline $\begin{array}{l}\text { Uranium }(1),(2) \\
\text { Elutriation } \\
\text { Efficiency, Percent }\end{array}$ & 76 & 85 & $123^{(3)}$ & 99 & 97 & 96 & $134^{(3)}$ & 66 & 51 & 51 & $137^{(3)}$ & ${ }_{--}^{(4)}$ & 88 & $102^{(3)}$ & 70 \\
\hline $\begin{array}{l}\text { Niobium Elutriation (1),(5) } \\
\text { Efficiency, Percent }\end{array}$ & 42 & 65 & 69 & 67 & 51 & 74 & 69 & 61 & 71 & 87 & 71 & $--^{(6)}$ & $\ldots(6)$ & 83 & 90 \\
\hline $\begin{array}{l}\text { Burner Heat } \\
\text { Generation } \\
\text { Rate, Btu/hr }\end{array}$ & 38,000 & 48,800 & 44,400 & 44,400 & 42,300 & 38,800 & 38,200 & 38,500 & 41,200 & 42,100 & 54,400 & 69,000 & 89,900 & 35,000 & 35,000 \\
\hline
\end{tabular}

(1) Uranium or niobium elutriation efficiency is the percent of that material charged which is found in the overhead product for the given run.

(2) Uranium concentration as a function of run time is shown in Figure 9 for Runs 1 through 8.

(3) Elutriation efficiencies in excess of 100 percent resulted from conducting several runs in sequence.

(4) No data obtained.

(5) Niobium concentration as a function of run time is shown in Figure 12 for Runs 1 through 8.

(6) Fuel charged did not contain niobium. 


\section{URANIUM CONCENTRATION IN THE BURNER}

The separation of $\mathrm{U}_{3} \mathrm{O}_{8}$ particles from the fluidized alumina bed occurs by elutriation. Early development studies showed that 90 percent of the $\mathrm{U}_{3} \mathrm{O}_{8}$ particles formed during oxidation of the uranium dicarbide microspheres were less than $45 \mu$ in diameter. Scoping studies, conducted in the single-stage burner, indicated the feasibility of $\mathrm{U}_{3} \mathrm{O}_{8}$ particle elutriation as a separation technique; steady-state concentrations of 2-to-4 weight percent were found in the bed.

Development studies in this area have focused on minimizing the uranium concentration in the burner. High concentrations of uranium in the burner are undesirable for two reasons: (1) a criticality danger could develop, and (2) the resulting increase in density requires more fluidizing gas for fluidization. Elimination of the criticality danger would require the periodic removal of the fluidized bed from the burner during a processing campaign unless the uranium concentration can be reduced.

Later studies in the single-stage burner showed that temperature excursions increased the uranium accumulation, but that continued operation reduced the concentration to the 2-to-4 percent range. Examination of the bed material from these runs indicated that much of the uranium present was coated on the surface of the alumina particles.

Experiments in the two-stage burner produced extremely random results (see Tables I and II). Several runs led to high concentrations of uranium in the burner, while low concentrations resulted from other experiments conducted under similar combustion conditions. This anomalous behavior was partially traced to differences in fuel composition and manufacturing techniques. However, the unavailability of complete composition and manufacturing data for Rover fuel elements thwarted attempts to correlate effects with fuel variations. Further, no apparent steady-state uranium concentration was attained in any of the two-stage burner runs.

On the basis of these conflicting results, statistically designed experiments to determine the factors involved in the uranium retention phenomenon were made in the miniburner. Bed temperature, burner pressure, and fluidizing velocity were the three major variables considered. Of these three variables, only bed temperature was found to have a significant effect on uranium retention at the 95 percent confidence level. Miniburner experiments were then made to further investigate the effect of temperature on uranium retention. One kilogram of fuel was burned in one kilogram of alumina in each experiment; the results are shown in Figure 8. 


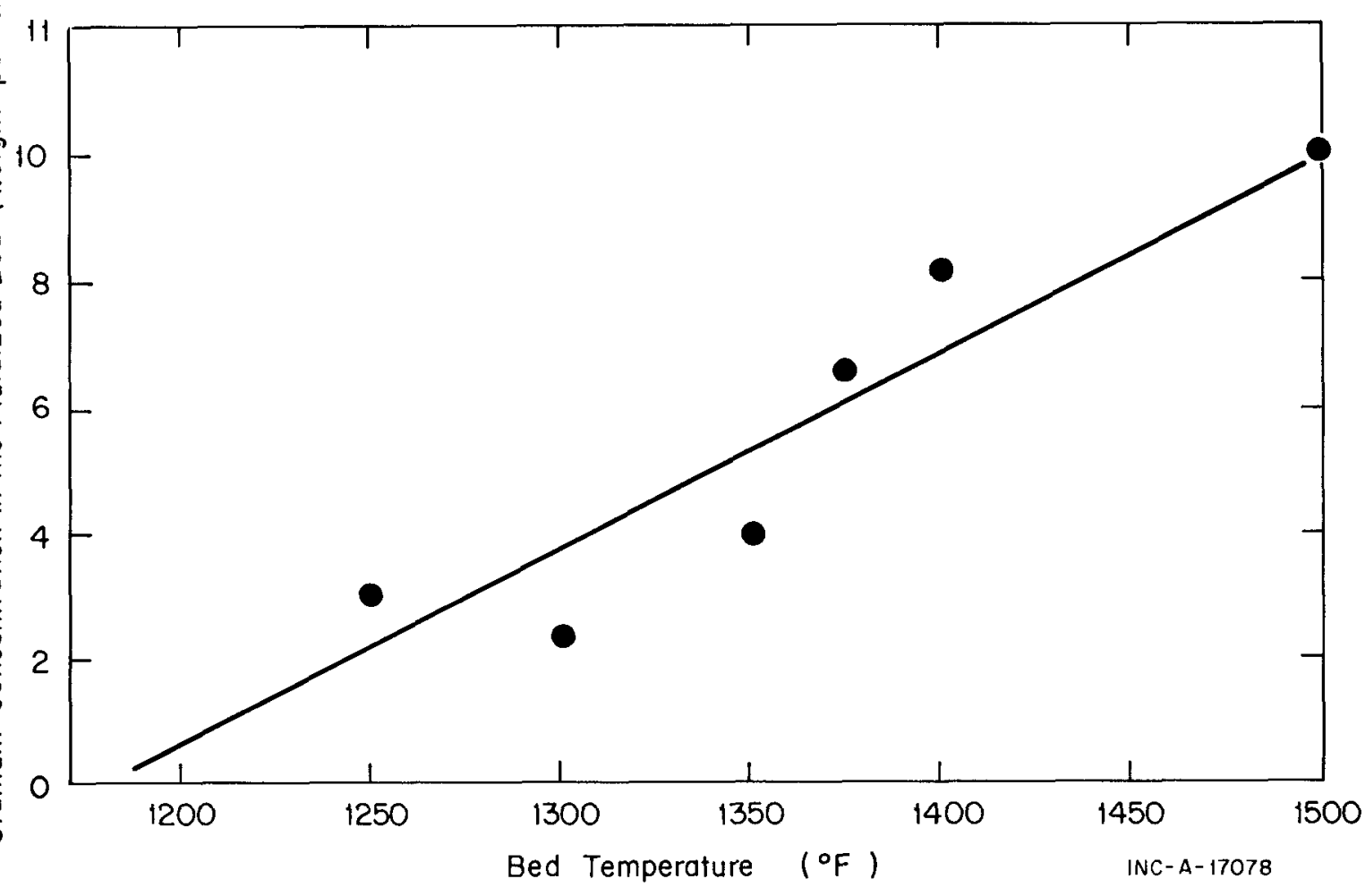

FIGURE 8

Effect of Nominal Bed Temperature on Uranium Retention in Fluidized Alumina Bed (Miniburner Results)

The miniburner tests indicated that the rate of uranium retention decreased as the $\mathrm{U}_{3} \mathrm{O}_{8}$ concentration in the bed increased. Investigations to determine if a steady-state concentration could be attained were started. A test conducted in the miniburner showed that the uranium concentration increased monotonically to a level (38 weight percent uranium) at which segregation of the bed material reduced the quality of fluidization to an unacceptable level. Thus, even if a steady-state uranium concentration exists for this set of operating conditions, i.e., feed rate, fuel type, and operating temperatures, it occurs in a concentration range which is not amenable to good quality fluidization.

To gain insight into the mechanism(s) of uranium retention, an intensive study of bed materials removed from the miniburner was made. Visual inspection of bed material having a high uranium content showed that $\mathrm{U}_{3} \mathrm{O}_{8}$ was present both as a coating and as spherical particles. The spherical particles ranged up to $200 \mu$ in diameter and were identified as essentially pure $\mathrm{U}_{3} \mathrm{O}_{8}$. Electron microprobe studies of a coated $\mathrm{Al}_{2} \mathrm{O}_{3}$ particle revealed that very little diffusion of $\mathrm{U}_{3} \mathrm{O}_{8}$ into the $\mathrm{Al}_{2} \mathrm{O}_{3}$ had occurred. The $\mathrm{U}_{3} \mathrm{O}_{8}$ spheres and the nature of the $\mathrm{U}_{3} \mathrm{O}_{8}$ coating on the $\mathrm{Al}_{2} \mathrm{O}_{3}$ surface suggested a molten history of this material. The postulated mechanism which evolved from this study was based on the high thermal conductivity of $\mathrm{UC}_{2}$ and the extremely exothermic nature of the oxidation reaction ( $1100 \mathrm{Kcal} / \mathrm{gram}-\mathrm{mole})$. The $\mathrm{UC}_{2}$ microspheres, upon oxidation, were postulated to form molten $\mathrm{U}_{3} \mathrm{O}_{8}$ particles which either formed solid $\mathrm{U}_{3} \mathrm{O}_{8}$ particles or collided with 
another bed particle, smearing on that particle surface, and solidifying. The possibility exists that conversion of the $\mathrm{UC}_{2}$ to $\mathrm{U}_{3} \mathrm{O}_{8}$ may not be complete prior to melting and disposition in the bed.

Uranium behavior in the two-stage concentric-bed burner is shown in Tables III and IV and in Figure 9. A statistically designed experiment, consisting of a series of eight 20-to-24 hour runs, was conducted to define the relationships between uranium retention rate and controllable process variables (fluidizing velocity, oxygen concentration). Effects of these variables on uranium retention were not found to be statistically significant (at the 95 percent confidence level); however, the experimental results were clearly confounded by errors inherent in the sampling of fluidized beds and by long-term transient responses. The uranium concentration in the bed for these consecutively-run experiments is shown in Figure 9. The data show no reversal or halting of uranium buildup in the bed.

Another phenomenon, discovered later in the development program, was the formation of nitric-acid $\left(\mathrm{HNO}_{3}\right)$ insoluble uranium. Since niobium-bearing fuel was burned early in the program (both in the pilot-plant and miniburner facilities) and no $\mathrm{HNO}_{3}$-insoluble uranium was detected, changes in fuel fabrication techniques are a suspected factor. Analytical results from a recent ten-day pilot-plant run in the concentric-bed burner showed that approximately 18 percent of the uranium in the product was insoluble in nitric acid (see Figure 10). $\mathrm{X}$-ray analysis of this material revealed that a major constituent of the insolubles is $\mathrm{Nb}_{3} \mathrm{UO}_{10}$, a $\mathrm{HNO}_{3}$-insoluble compound. Laboratory studies showed that $\mathrm{Nb}_{3} \mathrm{UO}_{10}$ can be formed by heating a mixture of $\mathrm{Nb}_{2} \mathrm{O}_{5}$ and $\mathrm{U}_{3} \mathrm{O}_{8}$ powders. Further, the formation rate was found to be a strong function of temperature; a significant amount of $\mathrm{Nb}_{3} \mathrm{UO}_{10}$ was formed at $2900^{\circ} \mathrm{F}$, while only negligible amounts formed at $1800^{\circ} \mathrm{F}$.

Although the above temperatures are higher than the fluidized-bed temperatures, the sites where oxidation reactions occur are at much higher temperatures than the nominal bed temperatures of 1250 to $1450^{\circ} \mathrm{F}$. The formation of $\mathrm{HNO}_{3}$-insoluble uranium compounds might occur at these sites. Therefore, the presence of substantial quantities of uranium and niobium in the fluidized bed and the availability of high-temperature regions are postulated to provide the conditions necessary for formation of significant amounts of $\mathrm{Nb}_{3} \mathrm{U} \mathrm{O}_{10}$.

Based on simple heat balance considerations, which show that actual site temperatures are functions of reaction rate and the rate of heat dissipation, the pilot-plant burner was operated at a low bed temperature $\left(1300\right.$ to $1350^{\circ} \mathrm{F}$ ) and a reduced inner-bed oxygen concentration (70 percent oxygen, 30 percent nitrogen). Oxygen availability was further decreased by reducing the fluidizing velocities in the inner and annular beds (to 1.0 and $1.1 \mathrm{ft} / \mathrm{sec}$, respectively).

Results from this run showed that 10 percent of the uranium in the overhead product was insoluble in nitric acid. Although this is a substantial improvement over the 18 percent insolubles produced at $1450^{\circ} \mathrm{F}$ and 100 percent oxygen in fluidizing gas, any significant $\mathrm{Nb}_{3} \mathrm{UO}_{10}$ 


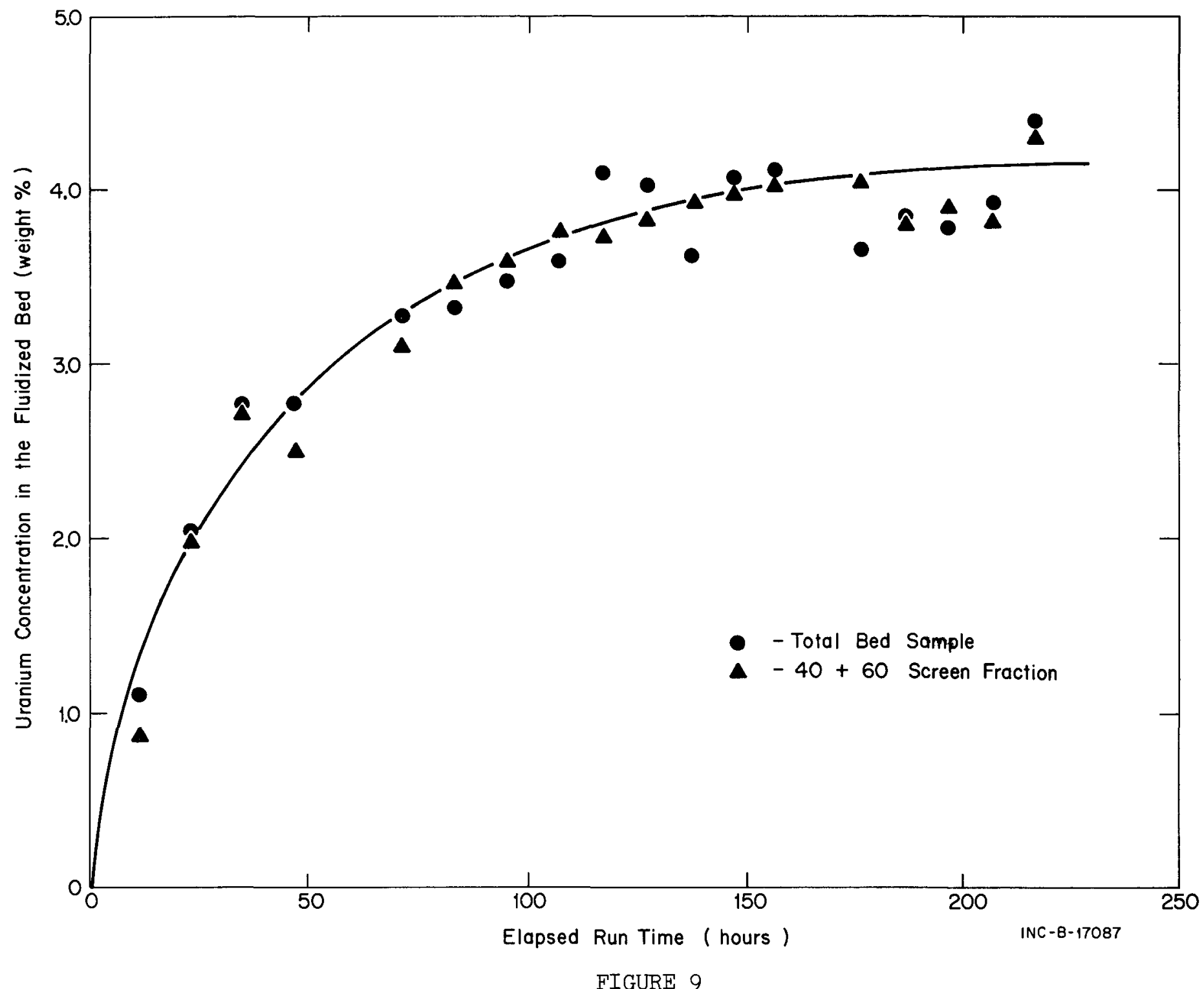

Uranium Retention in Fluidized Alumina Bed (Graphite Fuels Pilot Plant)

* -40 +60 Screen Fraction Corresponds to Alumina Particle Size Range. 


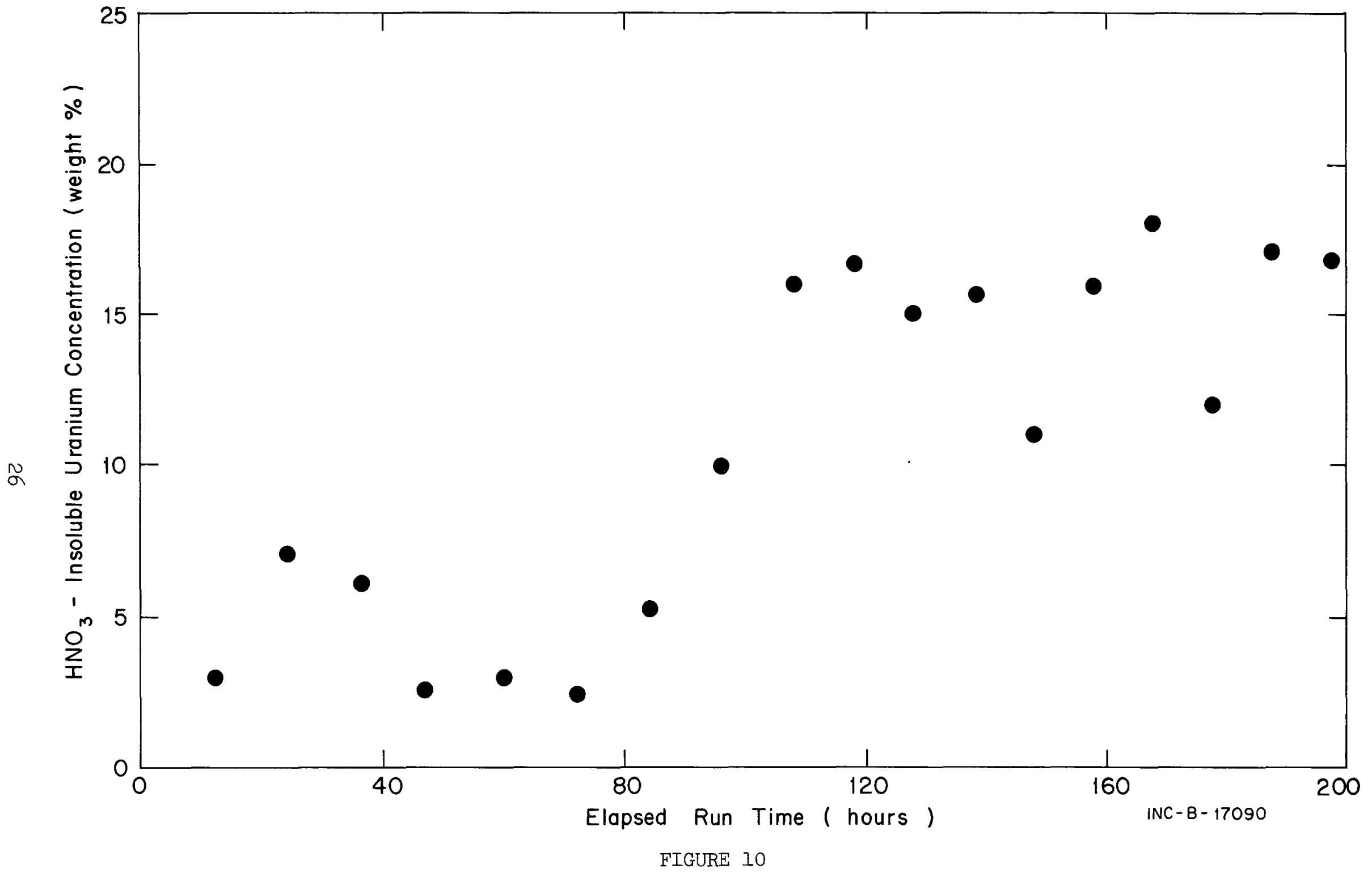

Nitric Acid-Insoluble Uranium Concentration in GFPP Burner Product

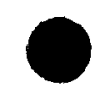


formation requires a leaching process other than the originallyproposed $\mathrm{HNO}_{3}$ system. Further, a reduction of bed temperature and oxygen concentration results in reduced çombustion efficiencies (less than 90 percent).

Uranium behavior in the fluidized-bed combustion process is, therefore, far more complex than originally envisioned. Summarizing, uranium carbide charged to the fluidized-bed burner can, upon oxidizing, (1) elutriate as $\mathrm{U}_{3} \mathrm{O}_{8}$ particles, (2) coat on the alumina particles, (3) form large, non-elutriable $\mathrm{U}_{3} \mathrm{O}_{8}$ spheres, or (4) react with niobium to form $\mathrm{HNO}_{3}$-insoluble compounds. Niobium-uranium compounds may either be retained in the burner or elutriated from the bed. Efforts to reduce the amount of uranium in the bed by controlling the process variables have met with limited or no success. These results indicate a need for controlling the uranium and niobium concentrations in the bed by a method independent of the controllable process variables. This conclusion led to the investigation of fet grinding as a method of decreasing the uranium and niobium concentrations in the bed.

The jet grinders used in the fluidized-bed combustion process are described and shown schematically in the Appendix. A high velocity air (or oxygen) stream accelerates the bed material, providing localized agitation. The uranium and niobium oxide particles, being more friable than the alumina, are preferentially reduced in size by attrition and elutriated from the burner. The $\mathrm{U}_{3} \mathrm{O}_{8}$ coating on the $\mathrm{Al}_{2} \mathrm{O}_{3}$ particles is broken and elutriated from the burner resulting in lower uranium concentrations in the fluidized bed.

A four-day pilot-plant run was conducted during which four jet grinders were operated for the first two days and turned off for the last two days. Figure 11 shows the effect of jet grinder operation on the amount of $\mathrm{HNO}_{3}$-insoluble uranium in the overhead product. Runs 14 and 15 in Tables III and IV represent the first two days and last two days of operation, respectively. The uranium elutriation efficiency of greater than 100 percent indicates that the jet grinders are capable of controlling uranium concentrations in the bed. Alumina attrition rates did not increase markedly as a result of jet-grinder operation, and combustion efficiency was acceptable. Therefore, jet grinders will be studied further as a means for controlling uranium and niobium concentrations in the burner.

Summary - Uranium Concentration in the Burner

Uranium behavior in the fluidized-bed combustion process is postulated as follows:

1. Uranium dicarbide microspheres, upon exposure to oxygen, react rapidly to a molten state. (Oxidation to $\mathrm{U}_{3} \mathrm{O}_{8}$ may or may not be complete.)

2. The action of the fluidized bed disperses the molten uranium particles in the bed where they solidify as $\mathrm{U}_{3} \mathrm{O}_{8}$ particles or collide with and solidify on the surface of $\mathrm{Al}_{2} \mathrm{O}_{3}, \mathrm{U}_{3} \mathrm{O}_{8}$, or $\mathrm{Nb}_{2} \mathrm{O}_{5}$ particles. 


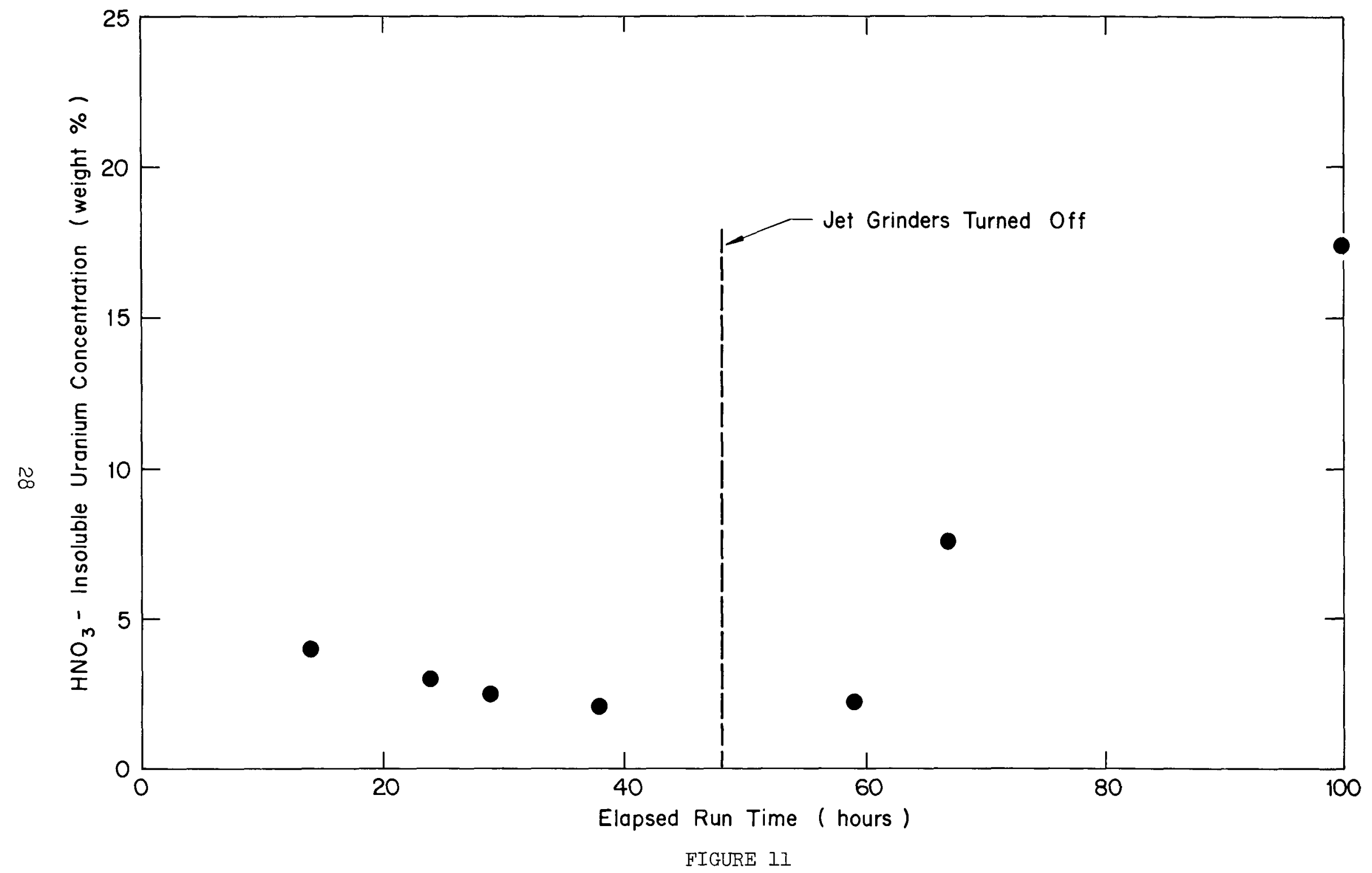

Effect of Jet Grinding on $\mathrm{HNO}_{3}$-Insoluble Uranium Formation in GFPP Burner Product (Initial Fluidized Bed Contained 15 Weight Percent $\mathrm{HNO}_{3}$-Insoluble Uranium) 
3. Most of the $\mathrm{U}_{3} \mathrm{O}_{8}$ particles (more than 90 weight percent of the uranium charged) elutriate from the burner.

4. Molten uranium which comes in contact with niobium in the burner may form $\mathrm{HNO}_{3}$-insoluble uranium-niobium compounds.

5. Jet grinding breaks up the uranium particles and, thus the uranium coating on $\mathrm{Al}_{2} \mathrm{O}_{3}$ particles to an elutriable size increasing the rate of elutriation from the burner.

6. In the absence of jet grinding, uranium retention in the burner is a strong function of bed temperature and fuel type.

\section{NIOBIUM CONCENTRATION IN THE BURNER}

Niobium carbide, present as a coating on some of the exposed surfaces of Rover fuel, oxidizes to $\mathrm{Nb}_{2} \mathrm{O}_{5}$ in the combustion process. Early in the development program, minimization of the niobium concentration in the burner was an objective because decreased quality of fluidization was anticipated with a large niobium buildup. The role of niobium in the formation of $\mathrm{HNO}_{3}$-insoluble uranium, discovered later in the program, increased the desirability of maintaining low niobium concentrations in the burner.

Examination of bed samples with the aid of a microscope indicates that niobium behavior in the combustion process is very dissimilar to that postulated for uranium. Apparently, $\mathrm{NbC}$ undergoes in situ oxidation; the $\mathrm{Nb}_{2} \mathrm{O}_{5}$ breaks into flakes as the oxidation of a fuel element proceeds. These flakes are later broken into various particle sizes by the turbulent action of the fluidized bed. Screen analyses of bed samples show that the bulk ( 75 percent) of the $\mathrm{Nb}_{2} \mathrm{O}_{5}$ retained in the burner (20 to 40 percent of the total niobium) is in the $-40 \pm 70$ (U. S. Sieve Series) fraction which corresponds to the size range of the $\mathrm{Al}_{2} \mathrm{O}_{3}$ bed material. Ten percent of the remaining niobium is larger than 40 mesh and may be present as pieces up to 1/2-inch long.

Three long-term pilot-plant tests have been made with niobiumbearing fuel. In the first two runs, a five-day and a ten-day operation, the $\mathrm{Nb}_{2} \mathrm{O}_{5}$ concentration in the fluidized bed increased at approximately the same rate ( 1.5 weight percent per 24 hours). Figure 12 shows niobium concentration during the ten-day run. During the third run, a continuation of the ten-day run, the niobium concentration remained relatively stable between 12 and 14 weight percent even though operating conditions were varied throughout the five days.

Although niobium oxide concentrations in the burner have not noticeably affected the quality of fluidization, the role which niobium plays in the formation of $\mathrm{HNO}_{3}$-insoluble uranium led to the use of jet grinders to minimize its concentration in the burner. Since it has been shown that $\mathrm{Nb}_{2} \mathrm{O}_{5}$ will react with $\mathrm{U}_{3} \mathrm{O}_{8}$ under the proper conditions, 


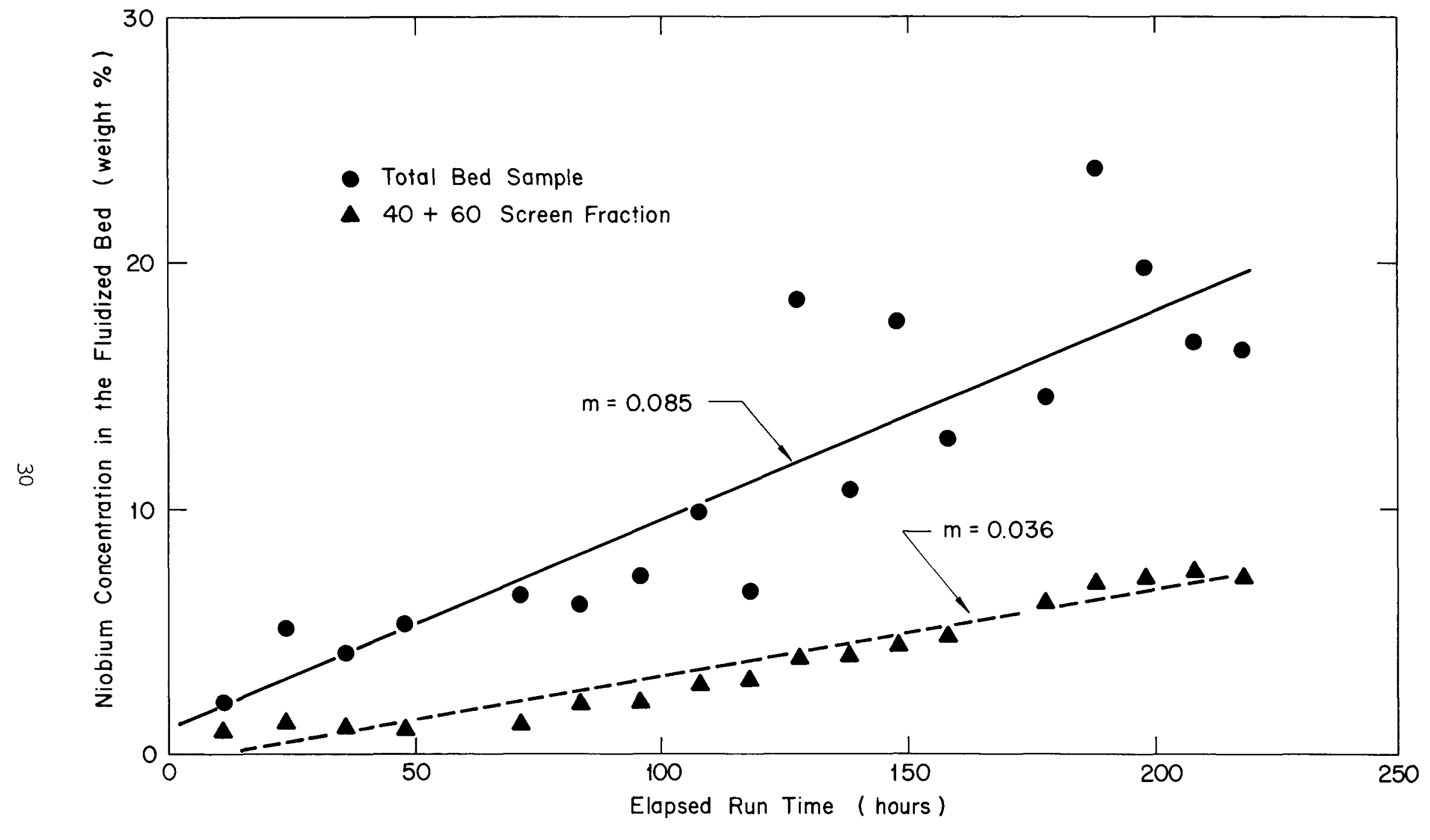

FIGURE 12

Niobium Retention in Fluidized Alumina Bed (Graphite Fuels Pilot Plant) 
reducing the concentration of niobium was expected to reduce the formation of $\mathrm{HNO}_{3}$-insoluble uranium.

The four-day pilot-plant operation (Runs 14 and 15), which was designed to test the effectiveness of jet grinders, showed the $\mathrm{Nb}_{2} \mathrm{O}_{5}$ retention rate reduced by 50 percent (to $\sim 0.75$ weight percent per 24 hours). While this buildup rate is excessive for plant operation, the significant rate decrease indicates that niobium concentration in the burner can be controlled by jet grinders. Further, the significant decrease in the production rate of $\mathrm{HNO}_{3}$-insoluble uranium compounds suggests that a further decrease in niobium concentration in the burner could result in further decreases in the amount of $\mathrm{HNO}_{3}$-insoluble uranium-niobium compounds.

\section{Summary - Niobium Concentration in the Burner}

Niobium carbide, present as a coating on some exposed surfaces of Rover fuel, oxidizes to $\mathrm{Nb}_{2} \mathrm{O}_{5}$ in the combustion process. Minimizing the niobium concentration is desirable for two reasons: (1) a large quantity of niobium oxide present in the bed will degrade the quality of fluidization, and (2) niobium combines with uranium to form $\mathrm{HNO}_{3}$ insoluble compounds.

Niobium carbide apparently undergoes in situ oxidation; the $\mathrm{Nb}_{2} \mathrm{O}_{5}$ breaking into large flakes as oxidation of the fuel element proceeds. Many of these flakes are broken into elutriable particles; however, the observed buildup rate prior to the introduction of jet grinders was approximately 1.5 weight percent per 24 hours. Four jet grinders installed in the pilot-plant burner reduced this rate to 0.75 weight percent per 24 hours. 


\section{CONCLUSIONS}

A fluidized-bed combustion process for separating uranium from the graphite matrix in Rover fuel elements has been developed at the ICPP. This process, conducted in a two-stage concentric-bed burner, consists of the following steps: (1) charging of whole or pieces of Rover elements to the burner, (2) oxidation of the graphite matrix and metallic carbides (uranium and niobium) in an inert bed of fluidized alumina, and (3) elutriation of the metal oxide combustion products from the alumina bed.

The primary objectives of the development program were to define a process which would (1) maximize combustion efficiency, (2) minimize the concentration of uranium and niobium in the burner, and (3) retain structural integrity over the proposed life of the Rover plant. Operation of the burner at 1400 to $1450^{\circ} \mathrm{F}$ with pure oxygen as the fluidizing gas resulted in combustion efficiencies greater than 95 percent at the proposed plant fuel charging rate $\left(16 \mathrm{~kg}\right.$ carbon $/$ hour $/ \mathrm{ft}^{2}$ of inner bed area). Jet grinders appear to be an effective means of maintaining low uranium and niobium concentrations in the burner. The concentric-bed burner has functioned reliably for more than 600 hours (greater than 25 percent of the maximum proposed plant processing campaign of 90 days). 


\section{FUTURE DEVELOPMENT STUDIES}

After a typical product ash is defined in the pilot-plant burner, a dissolution scheme will be developed to dissolve all uranium compounds formed in the burner; pilot-plant development of the fluidized-bed portion of the combustion process for Rover fuels is essentially complete. Process variable ranges have been determined and no major equipment changes are anticipated. Therefore, development efforts in the future will be directed to (1) definition of a suitable dissolution process for the product ash, (2) definition of solids handling equipment, (3) establishing conditions for optimum plant operation, and (4) determining the effect of scale-up on burner performance.

Should the $\mathrm{HNO}_{3}$-dissolution process be retained, additional development studies will be required to pinpoint the operating conditions for minimum formation of $\mathrm{HNO}_{3}$-insoluble uranium. Combustion of Rover fuel with $\mathrm{NO}_{2}$ is known to significantly reduce the amount of insolubles produced; however, combustion efficiencies in the existing equipment are greatly reduced by $\mathrm{NO}_{2}$. Therefore, modification of the burner equipment to increase particle residence times would likely be necessary. 
VII. REFERENCES

1. W. V. Goeddel, Coated Particle Fuels in High-Temperature Reactors: A Summary of Current Applications, GA-7650 (February 3, 1967).

2. E. L. Nicholson et al., Burn-Leach Processes for Graphite-Base Reactor Fuels Containing Carbon-Coated or Oxide Particles, ORNL-TM-1096 (April 2, 1965).

3. J. J. Reilly et al., "Fluidized-Bed Reprocessing of Graphite Matrix Nuclear Fuel", Industrial and Engineering Chemistry (Process Design and Development), 5 (January 1966) pp. 51-59.

4. D. C. Kilian et al., Description of the Pilot Plant for the Headend Reprocessing of Unirradiated Rover Fuels, IN-1181 (May 1968).

5. J. R. Bower (ed.), Chemical and Process Development Branch Annual Report: Fiscal Year 1966, IDO-14680 (October 1966).

6. J. R. Bower (ed.), Chemical Technology Branch Annual Report: Fiscal Year 1967, IN-1087 (October 1967).

7. J. R. Bower (ed.), Chemical Technology Branch Annual Report: Fiscal Year 1968, IN-1201 (October 1968).

8. J. R. Bower (ed.), Chemical Technology Branch Annual Report: Fiscal Year 1969, IN-1314 (October 1969).

9. M. Leva, Fluidization, New York: McGraw-Hill, p. 185.

10. Chin-Yung Wen and Richard F. Hasinger, "Elutriation of Solids Particles from a Dense-Phase Fluidized Bed", AIChE Journal, 6 (June 1960).

11. Sakae Yagi and Daizo Kunii, "Fluidized-Solids Reactors with Continuous Solids Feed--I Residence Time of Particles in Fluidized Beds", Chemical Engineering Science, 16 (December 1961) pp. 364-371.

12. E. Lopez - Menchero et al., Some Possibilities of Aqueous Processing of Graphite-Carbide Fuel Elements, Eurochemic Technical Report No. 172 (June 1965). 


\section{APPENDIX}

\section{TWO-STAGE CONCENTRIC FLUIDIZED-BED BURNER}

The first-stage of the concentric fluidized-bed is constructed of a 4-1/2-foot-long section of four-inch stainless steel (Type 304L, Schedule 40) pipe fitted with a flange at the lower end. A mating flange and cap with a $1 / 8$-inch thick sintered stainless steel disc between the flanges serves as a combination fluidizing-gas distributor and bed support plate. The upper two feet of the four-inch diameter pipe is slotted to facilitate heat and mass transfer between the inner and annular fluidized beds. Fuel elements are supported on a grid located six inches above the gas distributor plate.

The vessel which provides containment for both the annular and second-stage fluidized beds is a 12-1/2-foot-long section of six-inch (Type 316, Schedule 40) stainless steel pipe fitted with flanges at both ends. The fluidizing-gas distributor plate is a four-inch ID, sixinch OD ring of perforated plate ( 15 percent free area) welded to the external surface of the four-inch vessel and to the inner edge of a six-inch mating flange and cap assembly. The distributor plate serves as a support plate for the annular bed.

The fluidizing-gas flow rate to each stage of the burner is measured with integral-orifice, differential-pressure transmitters. The composition of the inlet fluidizing gas is controlled by using pure oxygen to maintain constant pressure upstream of the orifice while metering in the desired amount of air through a rotameter. Electrical resistance heating elements are used to preheat the two fluidizing-gas streams to $1000^{\circ} \mathrm{F}$.

A charging tube and baffle assembly, centered in the second stage and extending from the top of the burner to the top of the four-inch diameter first stage, allows fuel charging identical to that used in the original two-stage burner. The core of this assembly is a $1-1 / 4-$ inch fuel charging tube (Hastelloy C, Schedule 40). Two types of baffle plates surround the fuel charging tube and are secured in place by three 1/4-inch, Schedule 10, stainless steel pipes. The pipes contain 15 thermocouples used to measure temperatures in the second stage. Deflection baffles, located on six-inch centers from the top flange, reduce the amount of alumina bed material carried over in the off-gas. The second type of baffle is made of 1/8-inch perforated (3/8-inch holes, 23 percent open area) stainless steel discs. Nine of these baffles, spaced at nine-inch intervals reduce slugging by breaking up large bubbles.

Heat for burner startup and temperature control is supplied to both stages by external electrical resistance elements. Four of these elements surround the lower first-stage burner area, and two vertical 
banks of six elements each surround the lower six feet of the second stage. Electrical power to the heating elements surrounding both stages of the burner is controlled manually. Stainless steel shrouds surrounding the electrical elements act as heat reflectors and provide an annular space for cooling air flow.

Cooling air is supplied to the shrouds either by a blower mounted at the bottom of the burner module or by the laboratory utility air system. Two rotameters are used to regulate the air flow supplied by the laboratory system, while a butterfly valve regulates the air flow from the blower. The entire burner is insulated with high-temperature, magnesia insulation (3-inch thickness). Samples of the fluidized bed may be taken from five different points, bottom of the annular bed, bottom of the inner bed, and at the $3^{\prime} 8^{\prime \prime}, 6^{\prime} 5^{\prime \prime}$, and $9^{\prime} 1 I^{\prime \prime}$ bed heights in the second-stage burner.

Thermocouples located throughout the burner are monitored continuously on a multi-point recorder. Pressure drops across the sinteredmetal inner-bed support plate, the annular-bed support plate, the fluidized bed, and the filters in the dry collection vessel are recorded continuously. Bed level pressure probes are located at points 6-1/2 feet and $7-1 / 2$ feet above the bottom of the second stage.

Solids elutriated from the burner may either be collected in the dry product collection pot or introduced directly into the dissolution system. During dry product collection, solids are removed from the gas stream via two sintered metal filters located in the collection pot. A filter blowback system prevents excessive buildup of the solids on the filter surfaces. The desired burner pressure is maintained by a control valve located in the process line downstream of the sintered-metal filters.

Four jet grinders are located at the $3^{\prime} 3^{\prime \prime}, 4^{\prime} 1^{\prime \prime}, 4^{\prime} 8^{\prime \prime}$, and 6' 8" bed heights above the bottom of the first stage. They are devices which introduce a high-velocity air stream into the fluidized bed to give localized regions of agitation and a corresponding increase in solids attrition and elutriation rates. The jet-grinding units are constructed of 1/4-inch stainless steel tubing and extend through the burner wall to the approximate center of the fluidized bed. The "jet stream" passes through a $0.015-$ to 0.025 -inch diameter hole drilled perpendicular to the major axis of the tubing. A detailed sketch of the jet grinders used in the GFPP burner is shown in Figure 13.

\section{AUXILIARY EQUIPMENT}

\section{Miniburner}

The miniburner is a single-stage fluidized-bed burner two inches in diameter and twelve inches high. The unit was designed primarily as a scoping-studies tool; however, several series of detailed statistically-designed experiments which have proved useful to pilotplant work have been conducted in this equipment. The major advantage of this unit over the pilot-plant equipment is that investigations can be made more rapidly, at a lower cost, and involve smaller, subcritical 
quantities of enriched uranium. A more complete description of this equipment is included in $I N-1181$.

Glass Columns

Various glass columns ranging in size from one to six inches in diameter and three to fifteen feet high have been used for studies of the following:
(a) Two-stage fluidized bed
(b) Concentric fluidized beds
(c) Fuel charging
(d) The effect of baffle plates on fluidization
(e) The effect of baffle plates on particle residence times. 

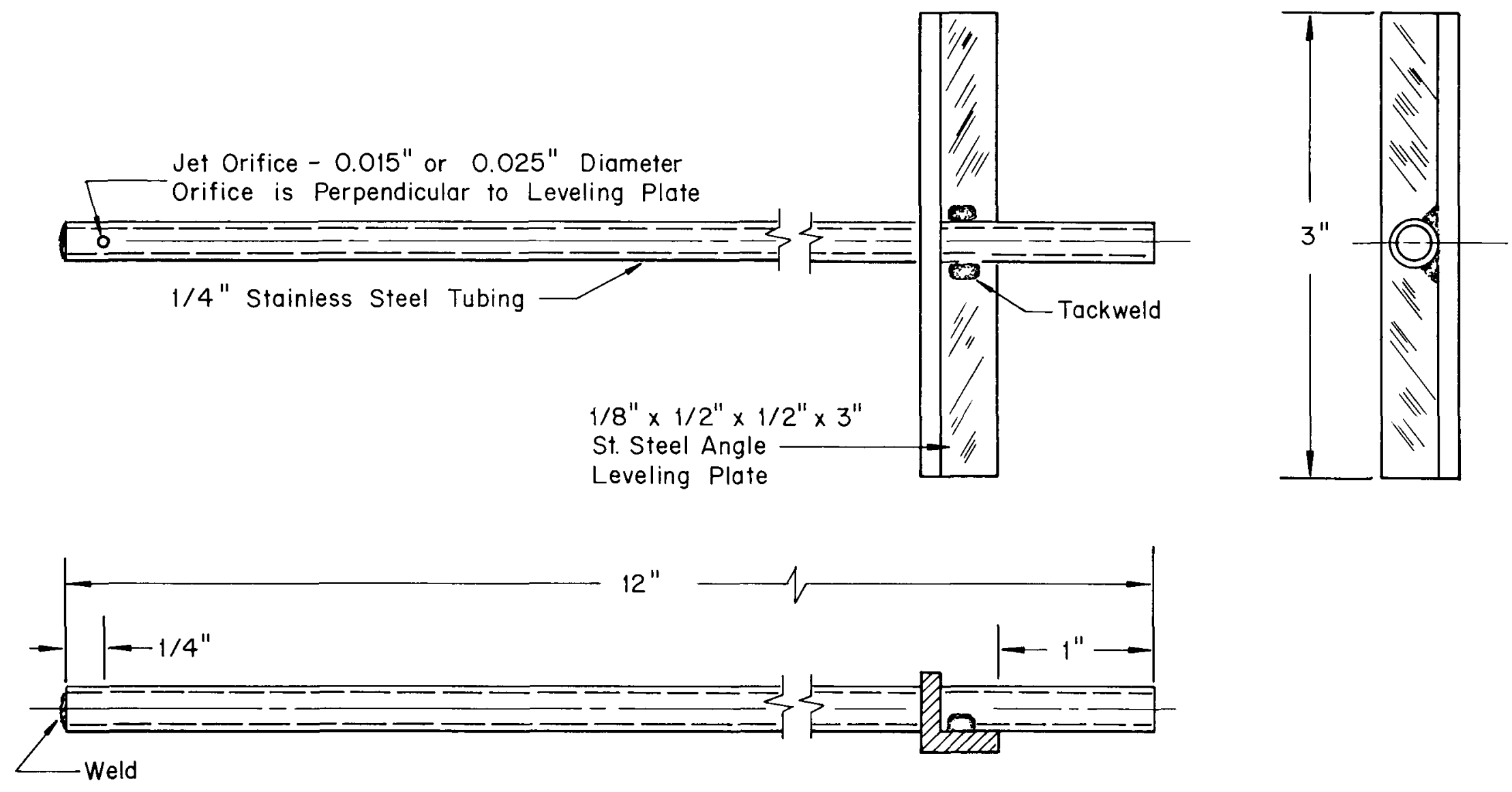

FIGURE 13

Jet Grinder Design Used in Graphite Fuels Burner 